\title{
Effects of nitrogen and phosphorus additions on nitrous oxide emission in a nitrogen-rich and two nitrogen-limited tropical forests
}

\author{
Mianhai Zheng ${ }^{1,5, *}$, Tao Zhang ${ }^{2, *}$, Lei Liu ${ }^{3}$, Weixing $\mathrm{Zhu}^{4}$, Wei Zhang ${ }^{1}$, and Jiangming Mo ${ }^{1}$ \\ ${ }^{1}$ Key Laboratory of Vegetation Restoration and Management of Degraded Ecosystems, South China Botanical Garden, \\ Chinese Academy of Sciences, 510650 Guangzhou, China \\ ${ }^{2}$ School of Life Science and Technology, Lingnan Normal University, 524048 Zhanjiang, China \\ ${ }^{3}$ State Key Laboratory of Urban and Regional Ecology, Research Center for Eco-Environmental Science, Chinese Academy \\ of Sciences, 100085 Beijing, China \\ ${ }^{4}$ Department of Biological Science, State University of New York, Binghamton, Binghamton, NY 13902, USA \\ ${ }^{5}$ University of Chinese Academy of Sciences, 100039 Beijing, China \\ ${ }^{*}$ These authors contributed equally to this work.
}

Correspondence to: Jiangming Mo (mojm@scib.ac.cn)

Received: 27 October 2015 - Published in Biogeosciences Discuss.: 18 January 2016

Revised: 13 April 2016 - Accepted: 27 May 2016 - Published: 16 June 2016

\begin{abstract}
Nitrogen (N) deposition is generally considered to increase soil nitrous oxide $\left(\mathrm{N}_{2} \mathrm{O}\right)$ emission in N-rich forests. In many tropical forests, however, elevated $\mathrm{N}$ deposition has caused soil $\mathrm{N}$ enrichment and further phosphorus $(\mathrm{P})$ deficiency, and the interaction of $\mathrm{N}$ and $\mathrm{P}$ to control soil $\mathrm{N}_{2} \mathrm{O}$ emission remains poorly understood, particularly in forests with different soil $\mathrm{N}$ status. In this study, we examined the effects of $\mathrm{N}$ and $\mathrm{P}$ additions on soil $\mathrm{N}_{2} \mathrm{O}$ emission in an $\mathrm{N}$-rich old-growth forest and two $\mathrm{N}$-limited younger forests (a mixed and a pine forest) in southern China to test the following hypotheses: (1) soil $\mathrm{N}_{2} \mathrm{O}$ emission is the highest in old-growth forest due to the N-rich soil; (2) $\mathrm{N}$ addition increases $\mathrm{N}_{2} \mathrm{O}$ emission more in the old-growth forest than in the two younger forests; (3) P addition decreases $\mathrm{N}_{2} \mathrm{O}$ emission more in the old-growth forest than in the two younger forests; and (4) $\mathrm{P}$ addition alleviates the stimulation of $\mathrm{N}_{2} \mathrm{O}$ emission by $\mathrm{N}$ addition. The following four treatments were established in each forest: Control, $\mathrm{N}$ addition $\left(150 \mathrm{~kg} \mathrm{Nha}^{-1} \mathrm{yr}^{-1}\right), \mathrm{P}$ addition $\left(150 \mathrm{~kg} \mathrm{Pha}^{-1} \mathrm{yr}^{-1}\right)$, and NP addition ( $150 \mathrm{~kg} \mathrm{Nha}^{-1} \mathrm{yr}^{-1}$ plus $\left.150 \mathrm{~kg} \mathrm{Pha}^{-1} \mathrm{yr}^{-1}\right)$. From February 2007 to October 2009, monthly quantification of soil $\mathrm{N}_{2} \mathrm{O}$ emission was performed using static chamber and gas chromatography techniques. Mean $\mathrm{N}_{2} \mathrm{O}$ emission was shown to be significantly higher in the old-growth forest $\left(13.9 \pm 0.7 \mu g \mathrm{~N}_{2} \mathrm{O}-\mathrm{N} \mathrm{m}^{-2} \mathrm{~h}^{-1}\right)$ than in the mixed $\left(9.9 \pm 0.4 \mu \mathrm{g} \mathrm{N} \mathrm{N}_{2} \mathrm{O}-\mathrm{N} \mathrm{m}^{-2} \mathrm{~h}^{-1}\right)$ or pine $\left(10.8 \pm 0.5 \mu \mathrm{g} \mathrm{N} \mathrm{N}_{2} \mathrm{O}\right.$ -
\end{abstract}

$\mathrm{N} \mathrm{m}^{-2} \mathrm{~h}^{-1}$ ) forests, with no significant difference between the latter two. $\mathrm{N}$ addition significantly increased $\mathrm{N}_{2} \mathrm{O}$ emission in the old-growth forest but not in the two younger forests. However, both P and NP addition had no significant effect on $\mathrm{N}_{2} \mathrm{O}$ emission in all three forests, suggesting that $\mathrm{P}$ addition alleviated the stimulation of $\mathrm{N}_{2} \mathrm{O}$ emission by $\mathrm{N}$ addition in the old-growth forest. Although $\mathrm{P}$ fertilization may alleviate the stimulated effects of atmospheric $\mathrm{N}$ deposition on $\mathrm{N}_{2} \mathrm{O}$ emission in $\mathrm{N}$-rich forests, this effect may only occur under high $\mathrm{N}$ deposition and/or long-term $\mathrm{P}$ addition, and we suggest future investigations to definitively assess this management strategy and the importance of $\mathrm{P}$ in regulating $\mathrm{N}$ cycles from regional to global scales.

\section{Introduction}

Nitrous oxide $\left(\mathrm{N}_{2} \mathrm{O}\right)$ is a long-lived (atmospheric lifetime of approximately 114 years) greenhouse gas that has 298 times the ability of carbon dioxide $\left(\mathrm{CO}_{2}\right)$ to trap heat in the atmosphere (Cicerone, 1987; IPCC, 2007). It has been recognized as a major ozone-depleting substrate in the 21 st century (Ravishankara et al., 2009). According to an estimation by the WMO (2012), atmospheric $\mathrm{N}_{2} \mathrm{O}$ concentration increased from $270 \mathrm{ppb}$ during preindustrial periods to $324.2 \mathrm{ppb}$ in 2011. The average emission rate of $\mathrm{N}_{2} \mathrm{O}$ in- 
creased by approximately $0.73-0.85 \mathrm{ppb} \mathrm{yr}^{-1}$ from 1999 to 2005 (Hirsch et al., 2006; IPCC, 2007) and is predicted to continue increasing during the following decades (Bouwman et al., 2013). Global estimations show that soils, including agricultural soils and soils under natural vegetation, are dominant sources of atmospheric $\mathrm{N}_{2} \mathrm{O}$ (Hirsch et al., 2006; IPCC, 2007; Bouwman et al., 2013).

Tropical forest soils are important sources of $\mathrm{N}_{2} \mathrm{O}$, which is mainly produced by nitrification and denitrification (IPCC, 2007; Bouwman et al., 2013). On global scales, over half of the $\mathrm{N}_{2} \mathrm{O}$ emissions occur in the tropics (D'Amelio et al., 2009), of which tropical forests account for approximately 14-23\% (IPCC, 2007). Because tropical forest soils are often rich in $\mathrm{N}$ but poor in $\mathrm{P}$, they are less able to retain external $\mathrm{N}$ input (Hall and Matson, 1999). With the greatest increases in atmospheric $\mathrm{N}$ deposition occurring in tropical regions (Galloway et al., 2008), tropical forests have shown a great increase in soil $\mathrm{N}_{2} \mathrm{O}$ emissions, compared with temperate and boreal forests (Matson and Vitousek, 1990). Although soil $\mathrm{N}_{2} \mathrm{O}$ emission is suggested to be regulated by soil temperature, moisture, $\mathrm{pH}$, and the availability of nutrients (Werner et al., 2007; Rowlings et al., 2012), current knowledge on the factors controlling $\mathrm{N}_{2} \mathrm{O}$ emission in tropical forests is poor. This is not only because tropical forests have complicated structures and functions, as well as great temporal and spatial variations of $\mathrm{N}_{2} \mathrm{O}$ fluxes (D'Amelio et al., 2009; J. Zhu et al., 2013), but also because only a small number of studies in tropical forests is available (Dalal and Allen, 2008; Liu and Greaver, 2009).

During recent decades, elevated atmospheric $\mathrm{N}$ deposition caused by anthropogenic activities has greatly altered terrestrial $\mathrm{N}$ cycles, reducing $\mathrm{N}$ input via biological $\mathrm{N}$ fixation and increasing $\mathrm{N}$ losses via $\mathrm{NO}_{3}^{-}$leaching and $\mathrm{N}_{2} \mathrm{O}$ emission (Vitousek et al., 1997; Galloway et al., 2004). It is estimated that reactive $\mathrm{N}$ deposition increased from $34 \mathrm{Tg} \mathrm{N} \mathrm{yr}^{-1}$ in 1860 to $100 \mathrm{Tg} \mathrm{Nyr}^{-1}$ in 1995 and is expected to reach $200 \mathrm{Tg} \mathrm{N} \mathrm{yr}^{-1}$ by 2050 globally (Galloway et al., 2008). Tropical forests are often rich in $\mathrm{N}$, and thus $\mathrm{N}$ deposition into such ecosystems will exceed their capacity for $\mathrm{N}$ retention (Aber et al., 1989), leading to rapid $\mathrm{N}$ losses via liquid leaching and gases emission (such as $\mathrm{N}_{2}, \mathrm{~N}_{2} \mathrm{O}$, NO, $\mathrm{NH}_{3}$, and HONO). There are some field studies showing that $\mathrm{N}$ addition increased $\mathrm{N}_{2} \mathrm{O}$ emission in forests. For example, Hall and Matson (1999) reported significant increases in soil $\mathrm{N}_{2} \mathrm{O}$ emission after both short-term and long-term $\mathrm{N}$ addition in two Hawaiian forests. Zhang et al. (2008b) suggested that $\mathrm{N}$ addition elevated soil $\mathrm{N}_{2} \mathrm{O}$ emission more readily in N-rich than $\mathrm{N}$-limited forest. In a secondary tropical forest, Wang et al. (2014) also found a significant increase in $\mathrm{N}_{2} \mathrm{O}$ emission after 3 years of $\mathrm{N}$ fertilization. A metaanalysis by Liu and Greaver (2009) showed that $\mathrm{N}$ addition (10-562 $\mathrm{kg} \mathrm{N} \mathrm{ha}^{-1} \mathrm{yr}^{-1}$ ) significantly increased $\mathrm{N}_{2} \mathrm{O}$ emission by approximately $216 \%$ across all ecosystems, among which tropical forests emitted the most.
In contrast to typically $\mathrm{N}$-limited temperate forests, many tropical forests on highly weathered soils are rich in $\mathrm{N}$ but limited by phosphorus (P) (Vitousek and Matson, 1988; Vitousek et al., 2010). Hall and Matson (1999) reported that Plimited soils could emit more $\mathrm{N}_{2} \mathrm{O}$ than $\mathrm{N}$-limited soils after $\mathrm{N}$ addition, suggesting an important role of $\mathrm{P}$ in controlling soil $\mathrm{N}_{2} \mathrm{O}$ emission. However, to date, studies on P-addition effects on soil $\mathrm{N}_{2} \mathrm{O}$ emission have mainly relied on incubation experiments (Sundareshwar et al., 2003; Mori et al., 2010, 2013; Baral et al., 2014) or have been limited to two tropical plantations (Mori et al., 2014; Zhang et al., 2014) and a secondary forest (Wang et al., 2014). Generally, these studies reported a decrease in soil $\mathrm{N}_{2} \mathrm{O}$ emission following $\mathrm{P}$ fertilization given the consequent increases in plant $\mathrm{N}$ uptake and/or microbial $\mathrm{N}$ immobilization, and thus reduced soil $\mathrm{N}$ availability for $\mathrm{N}_{2} \mathrm{O}$ production (Sundareshwar et al., 2003; Baral et al., 2014; Mori et al., 2014; Zhang et al., 2014). Only Mori et al. $(2010,2013)$ found a positive response of $\mathrm{N}_{2} \mathrm{O}$ emission to $\mathrm{P}$ addition, suggesting that $\mathrm{P}$ addition may stimulate soil $\mathrm{N}$ cycles and alleviate $\mathrm{P}$ limitation on nitrifying and denitrifying bacteria. Other than the studies above, similar work has not been carried out in other natural tropical forests. Moreover, in tropical forests with N-rich and Plimited conditions, the interaction of $\mathrm{N}$ and $\mathrm{P}$ to control soil $\mathrm{N}_{2} \mathrm{O}$ emission remains poorly understood (Hall and Matson, 2003; Wang et al., 2014).

We hypothesize that $\mathrm{P}$ addition may reduce soil $\mathrm{N}_{2} \mathrm{O}$ emission in tropical forests based on two lines of evidences. First, in several P-limited tropical forests or plantations, $\mathrm{P}$ addition significantly increased root $\mathrm{N}$ uptake capacity (Treseder and Vitousek, 2001) and aboveground plant $\mathrm{N}$ contents (Fernandez et al., 2000; Pampolina et al., 2002; Graciano et al., 2006). Second, our previous study found that $P$ addition significantly increased soil microbial communities (Liu et al., 2012) and marginally increased microbial biomass N (Liu et al., 2013) in an N-rich tropical forest. Such findings indicate the potential capacity of $\mathrm{P}$ to increase $\mathrm{N}$ uptake and immobilization, thus decreasing $\mathrm{N}$ losses in tropical forests. However, the capacity of $\mathrm{P}$ to reduce $\mathrm{N}$ losses may be related to forest development. Despite many tropical forests having $\mathrm{N}$-rich soils, several younger forests early in soil development are still N-limited (Vitousek et al., 1997). Compared with the old-growth forests, younger forests often show the higher $\mathrm{N}$ demands and utilization of plants and microbes but the lower rates of soil $\mathrm{N}$ cycling, such as mineralization, nitrification, and leaching (Aber et al., 1998). In contrast, oldgrowth forests have the higher $\mathrm{P}$ demand because they are commonly depleted in P (Vitousek et al., 2010). For example, a previous study showed that soil microbes and/or tree roots released more phosphatase in an old-growth forest than in the younger one (Zheng et al., 2015). Based on this evidence and considering current knowledge gaps regarding nutrient $(\mathrm{N}$ and $\mathrm{P}$ ) control of $\mathrm{N}_{2} \mathrm{O}$ emission in tropical forests, we conducted a randomized factorial-design experiment to investigate the effects of $\mathrm{N}$ and $\mathrm{P}$ addition on soil $\mathrm{N}_{2} \mathrm{O}$ emission in 
three tropical forests in southern China: an N-rich old-growth forest and two $\mathrm{N}$-limited younger forests (a mixed and a pine forest). We hypothesized that (1) soil $\mathrm{N}_{2} \mathrm{O}$ emission is the highest in old-growth forest due to the N-rich soil, (2) $\mathrm{N}$ addition increases $\mathrm{N}_{2} \mathrm{O}$ emission more in the old-growth forest than in the two younger forests, (3) $\mathrm{P}$ addition decreases $\mathrm{N}_{2} \mathrm{O}$ emission more in the old-growth forest than in the two younger forests, and (4) $\mathrm{P}$ addition alleviates the stimulation of $\mathrm{N}_{2} \mathrm{O}$ emission by $\mathrm{N}$ addition.

\section{Materials and methods}

\subsection{Site description}

This study was conducted in the Dinghushan Biosphere Reserve (DHSBR), located in the center of Guangdong Province, southern China $\left(112^{\circ} 10^{\prime} \mathrm{E}, 23^{\circ} 10^{\prime} \mathrm{N}\right)$. The reserve occupies an area of approximately 1200 ha and includes three forests: an old-growth forest and two younger forests (a mixed broadleaf-pine forest and a pine forest). The old-growth forest has been well protected from human disturbance for over 400 years, with major species such as Castanopsis chinensis Hance, Schima superba Chardn. \& Champ., Cryptocarya chinensis (Hance) Hemsl., Cryptocarya concinna Hance, Machilus chinensis (Champ. ex Benth.) Hemsl., and Syzygium rehderianum Merr. \& Perry in the tree layer and Calamus rhabdicladus Burret, Ardisia quinquegona $\mathrm{Bl}$., and Hemigramma decurrens (Hook.) Copel. in the understory layer (Wang et al., 1982). The two younger forests both originated from a 1930s clear-cut and subsequent pine plantation establishment (Mo et al., 2006, 2007b). They experienced continuous human disturbance (the harvesting of understory and litter) from 1930 to 1956 (mixed forest) and 1998 (pine forest). Because of the colonization from the natural dispersal of regional broadleaf species, the mixed forest contains both pine- and broadleaf-tree species (Mo et al., 2003, 2007b). The mixed forest is dominated by Pinus (P) massoniana, Schima superba Chardn. \& Champ., Castanopsis chinensis Hance, Craibiodendron kwangtungense S. Y. Hu, Lindera metcalfiana Allen, and Cryptocarya concinna Hance, while the pine forest is dominated by $P$. massoniana.

Earlier studies suggested that $22-28 \mathrm{~kg} \mathrm{Nha}^{-1} \mathrm{yr}^{-1}$ were retained in the upper $20 \mathrm{~cm}$ soil and the plant biomass (including canopy trees, understory plants, and forest litter) in the two younger forests and that a net loss of 8 $16 \mathrm{~kg} \mathrm{~N} \mathrm{ha}^{-1} \mathrm{yr}^{-1}$ mainly via dissolve inorganic $\mathrm{N}\left(\mathrm{NH}_{4}^{+}\right.$and $\mathrm{NO}_{3}^{-}$) leaching and soil $\mathrm{N}_{2} \mathrm{O}$ emission occurred in the oldgrowth forest (Fang et al., 2008). This indicates $\mathrm{N}$ saturation in the old-growth forest but $\mathrm{N}$ limitation in the two younger ones. Different soil $\mathrm{N}$ status is also supported by different litter decomposition rates, with negative $\mathrm{N}$ effects in the oldgrowth forest but positive effects in the two younger forests (Mo et al., 2006). The N-rich status of the old-growth for- est is also directly supported by its higher foliar $\mathrm{N}: \mathrm{P}$ ratios (20.6-36.8) compared with the two younger forests (13.8 in pine forest and 17.8-24.4 in mixed forest; Huang et al., 2013). However, soil $P$ is deficient in the old-growth forest, as evidenced by the positive responses of soil $\mathrm{CH}_{4}$ uptake (Zhang et al., 2011), microbial biomass (Liu et al., 2012) and live fine-root biomass (F. Zhu et al., 2013) to P addition.

The reserve has a typical humid monsoon climate with an average annual precipitation of $1927 \mathrm{~mm}$, about $75 \%$ of which falls from March to August and only $6 \%$ from December to February as reported by our previous studies (Huang and Fan, 1982; Lu et al., 2013). The mean annual temperature is $21^{\circ} \mathrm{C}$, with a January mean temperature of $12.6^{\circ} \mathrm{C}$ and July mean temperature of $28.0^{\circ} \mathrm{C}$; annual mean relative humidity is $80 \%$ (Huang and Fan, 1982). Wet inorganic $\mathrm{N}$ deposition was 34, 24, and $26 \mathrm{~kg} \mathrm{Nha}^{-1} \mathrm{yr}^{-1}$ in 2004 and 2005 for the old-growth, mixed, and pine forests, respectively, with an additional input of $15-20 \mathrm{~kg} \mathrm{Nha}^{-1} \mathrm{yr}^{-1}$ as dissolved organic N (Fang et al., 2008). All forest soils are lateritic red earth formed from sandstone, and soil depth is $<30,30-60$, and $>60 \mathrm{~cm}$ in the old-growth, mixed, and pine forests, respectively (Mo et al., 2003). General soil properties are listed in Table 1.

\subsection{Experimental design}

The experiment was established in 2007 with five replicates of each four treatments in each forest: Control (no fertilization), $\mathrm{N}$ addition (150 $\left.\mathrm{kg} \mathrm{Nha}^{-1} \mathrm{yr}^{-1}\right), \mathrm{P}$ addition $\left(150 \mathrm{~kg} \mathrm{Pha}^{-1} \mathrm{yr}^{-1}\right)$, and NP addition $\left(150 \mathrm{~kg} \mathrm{Nha}^{-1} \mathrm{yr}^{-1}\right.$ plus $\left.150 \mathrm{~kg} \mathrm{Pha}^{-1} \mathrm{yr}^{-1}\right)$,with a total of 20 plots $(5 \mathrm{~m} \times 5 \mathrm{~m})$. Each plot was surrounded by a $5 \mathrm{~m}$ wide buffer strip. We used the high $\mathrm{N}$ gradient, about 3 times the atmospheric $\mathrm{N}$ deposition rate, because many soil processes responded significantly only under this gradient in the old-growth forest (Mo et al., 2008; Zhang et al., 2008a; Lu et al., 2010). A high $\mathrm{P}$ gradient was used because of the high $\mathrm{P}$ demand of soil microbes in the old-growth forest (Liu et al., 2012). Although the two younger forests are N-limited, we used similar $\mathrm{N}$ and $\mathrm{P}$ gradients for the main purpose of comparison among the forests (Zheng et al., 2015; Zhu et al., 2013a). High fertilization rates can remove all possible $\mathrm{N}$ and $\mathrm{P}$ constraints in both young and old-growth forests (Cleveland and Townsend, 2006). In addition, plot size and fertilizer level in our forests were also the same as those studied in Costa Rica by Cleveland and Townsend (2006). All plots and treatments were assigned randomly. $\mathrm{NH}_{4} \mathrm{NO}_{3}$ and $\mathrm{NaH}_{2} \mathrm{PO}_{4}$ solutions were used as fertilizers and sprayed below the canopy using a backpack sprayer, bimonthly from February 2007 to October 2009. Fertilizer was weighed and mixed with $5 \mathrm{~L}$ of water for each plot. Each control plot received $5 \mathrm{~L}$ of water without fertilizer. 
Table 1. General characteristics of the $0-10 \mathrm{~cm}$ mineral soils in the three study forests.

\begin{tabular}{|c|c|c|c|}
\hline Forest type & Old-growth forest & Mixed forest & Pine forest \\
\hline $\mathrm{pH}$ value $\left(\mathrm{H}_{2} \mathrm{O}\right)$ & $3.9(0.0) \mathrm{b}$ & $4.0(0.0) \mathrm{a}$ & $4.0(0.1) \mathrm{ab}$ \\
\hline $\mathrm{NH}_{4}^{+}\left(\mathrm{mg} \mathrm{kg}^{-1}\right)$ & $2.4(0.3) \mathrm{a}$ & $1.4(0.1) b$ & $2.4(0.0) \mathrm{a}$ \\
\hline $\mathrm{NO}_{3}^{-}\left(\mathrm{mg} \mathrm{kg}^{-1}\right)$ & $4.3(0.3) \mathrm{a}$ & $1.3(0.2) \mathrm{c}$ & $3.3(0.5) b$ \\
\hline Dissolve organic $\mathrm{C}\left(\mathrm{mg} \mathrm{kg}^{-1}\right)$ & $709.2(33.7) \mathrm{a}$ & $552.3(13.9) \mathrm{b}$ & $573.2(25.2) \mathrm{b}$ \\
\hline Soil organic C $(\%)$ & $4.1(0.2) \mathrm{a}$ & $2.8(0.2) \mathrm{b}$ & $2.9(0.3) \mathrm{b}$ \\
\hline Microbial biomass $\mathrm{C}\left(\mathrm{mg} \mathrm{kg}^{-1}\right)$ & $551.9(38.5) \mathrm{a}$ & $75.9(7.0) \mathrm{c}$ & $165.6(10.3) \mathrm{b}$ \\
\hline Available P $\left(\mathrm{mg} \mathrm{kg}^{-1}\right)$ & $2.1(0.4) \mathrm{a}$ & $0.9(0.1) b$ & $1.1(0.2) b$ \\
\hline Total $\mathrm{N}\left(\mathrm{g} \mathrm{kg}^{-1}\right)$ & $1.6(0.1) \mathrm{a}$ & $1.1(0.2) \mathrm{b}$ & $1.1(0.1) b$ \\
\hline Total P $\left(\mathrm{mg} \mathrm{g}^{-1}\right)$ & $0.5(0.0)$ & $0.5(0.0)$ & $0.5(0.0)$ \\
\hline $\mathrm{N}: \mathrm{P}$ ratios & $3.2(0.2) \mathrm{a}$ & $2.2(0.2) b$ & $2.3(0.3) b$ \\
\hline
\end{tabular}

Notes: soil samples were collected in February 2007. Values are means with standard error in parentheses $(n=5)$. Different lowercase letters indicate significant differences among forests, as determined by one-way ANOVA $(P<0.05)$.

\section{$2.3 \quad \mathrm{~N}_{2} \mathrm{O}$ flux measurement}

$\mathrm{N}_{2} \mathrm{O}$ fluxes were measured from January 2007 before the first fertilizer application. Two static chambers were installed in each plot in November 2006, 2 months prior to the gas sampling. The chamber design and measurement method were adopted from Zhang et al. (2011). Gas fluxes were monitored monthly using a static chamber and a gas chromatograph (Agilent 4890D). Each static chamber consisted of an anchor ring and a removable cover chamber. The anchor ring was a PVC pipe $(25 \mathrm{~cm}$ diameter and $16 \mathrm{~cm}$ height) permanently anchored in the soil at $8 \mathrm{~cm}$ depth. During gas collection, a removable cover chamber $(25 \mathrm{~cm}$ diameter and $30 \mathrm{~cm}$ height) was attached tightly to the anchor ring using a rubber O-ring seal. Gas samples were collected from each chamber from 09:00 to 10:00 LT, during which the greenhouse gas fluxes are closer to the daily means (Tang et al., 2006). Gas samples were taken with a $60 \mathrm{~mL}$ plastic syringe at 0,15 , and 30 min intervals after the chamber closure. Before each sampling, syringes were flushed three times with chamber gas to mix the headspace. The gas samples were analyzed within $12 \mathrm{~h}$ on a gas chromatograph (Agilent 4890D) fitted with an electron capture detector (ECD) for $\mathrm{N}_{2} \mathrm{O}$. Two stainless steel columns (pre-column and main column were $1 \mathrm{~m}$ and $3 \mathrm{~m}$ in length, respectively) packed with Porapak $\mathrm{Q}$ were used to separate $\mathrm{N}_{2} \mathrm{O}$. The oven temperature and ECD temperature were 55 and $330^{\circ} \mathrm{C}$, respectively. To avoid the interference of $\mathrm{CO}_{2}$ from the gas samples, which can lead to an overestimation of $\mathrm{N}_{2} \mathrm{O}$ fluxes as suggested by Zheng et al. (2008), we used $\mathrm{N}_{2}$ as the carrier gas (flow rate of $35 \mathrm{~mL} \mathrm{~min}^{-1}$ ) and introduced $10 \%$ of $\mathrm{CO}_{2}$ in $\mathrm{N}_{2}$ as the make-up gas (flow rate of $2 \mathrm{~mL} \mathrm{~min}^{-1}$ ) into the ECD (Wang et al., 2010). Through introducing a high concentration and low flow rate of $\mathrm{CO}_{2}$ into the ECD, the interference of $\mathrm{CO}_{2}$ from the gas samples is negligible (Wang et al., 2010). Calibration gases $\left(\mathrm{N}_{2} \mathrm{O}\right.$ at 321 ppbv, bottle no. 070811) were obtained from the Institute of Atmospheric Physics, Chinese Academy of Sciences.
The calculation of $\mathrm{N}_{2} \mathrm{O}$ fluxes followed the method of Holland et al. (1999), based on the linear regression of chamber gas concentration with time. Atmospheric pressure was measured at the sampling sites using an air pressure gauge (Model THOMMEN 2000, Switzerland). Meanwhile, air temperature (enclosure), soil temperature (at $5 \mathrm{~cm}$ depth), and moisture $(0-10 \mathrm{~cm}$ depth) inside each chamber were measured during each sampling. Soil moisture content was detected using a TDR probe (Model Top TZS-I, China) and converted to water-filled pore space (WFPS) according to the following formula:

$\mathrm{WFPS}=\mathrm{Vol} /(1-\mathrm{SBD} / 2.65)$.

SBD: soil bulk density $\left(\mathrm{g} \mathrm{cm}^{-3}\right)$; Vol: volumetric water moisture (\%); $2.65 \mathrm{~g} \mathrm{~cm}^{-3}$ is the assumed particle density in mineral soil of forests (Linn and Doran, 1984). It is possible that the particle density value may be different between forest types (old-growth vs. younger forests), but we focused on the comparison between treatments in this study, so this case is of minor importance.

\subsection{Soil sample analyses}

Soil sampling was conducted in February 2007 (before the first fertilizer application), August 2007, February 2008, August 2008, February 2009, and August 2009. Five soil cores $(2.5 \mathrm{~cm}$ inner diameter) were collected randomly from 0 to $10 \mathrm{~cm}$ soil depths and mixed by plot. Soil $\mathrm{pH}$ was measured in a soil-water (1:2.5) suspension. Soil organic carbon (C) was measured using dichromate oxidation and titration with ferrous ammonium sulfate (Liu et al., 1996). Soil microbial biomass $\mathrm{C}$ was measured using the chloroform fumigationextraction method (Vance et al., 1987). Soil dissolved organic $\mathrm{C}$ was extracted with $0.5 \mathrm{M} \mathrm{K}_{2} \mathrm{SO}_{4}$ and analyzed using a total carbon analyzer (Shimadzu model TOC-500, Kyoto, Japan). Total $\mathrm{N}$ concentration was measured using semimicro-Kjeldahl digestion followed by the detection of 


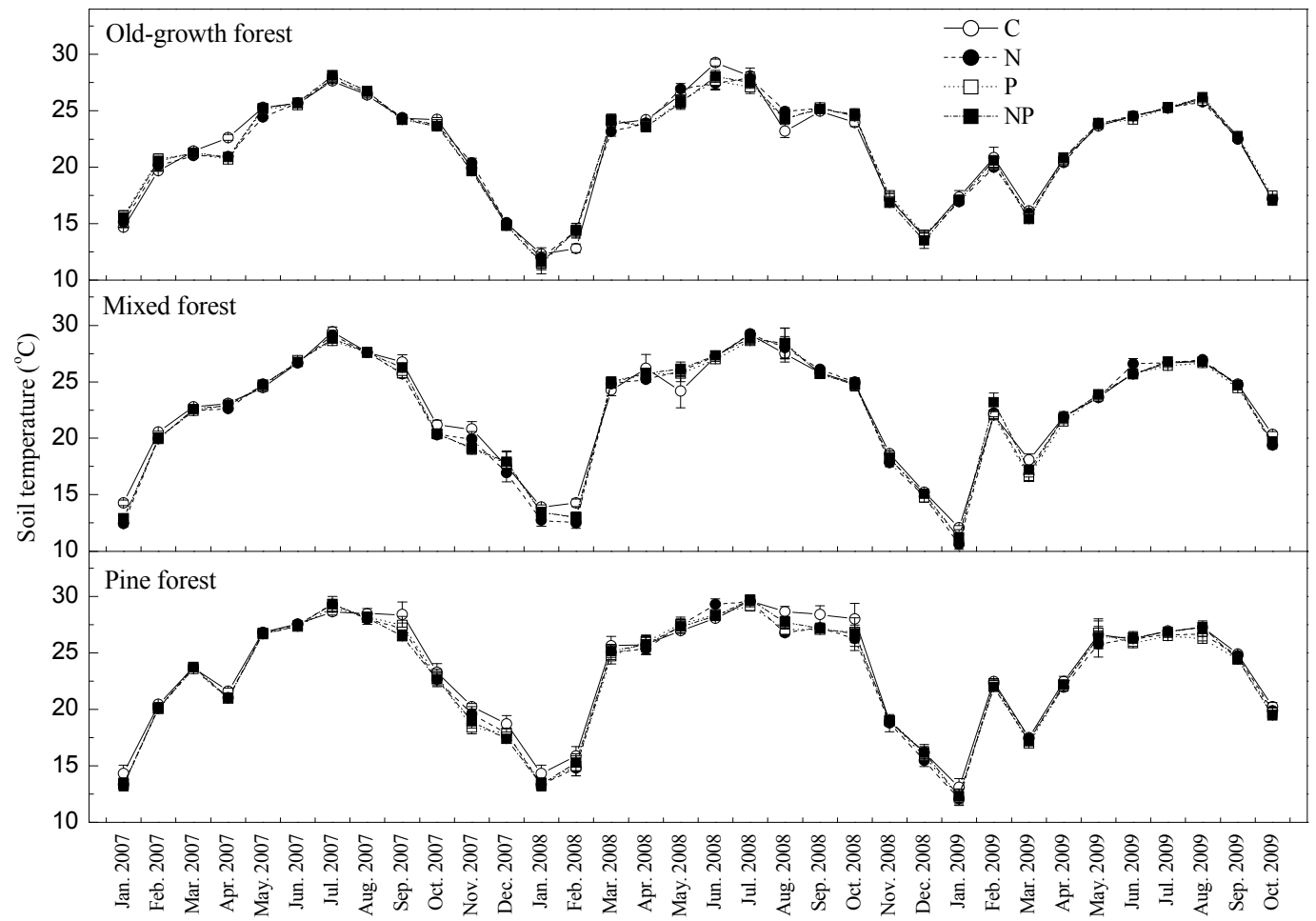

Figure 1. Monthly soil temperature in the three study forests of Dinghushan Biosphere Reserve (DHSBR) from January 2007 to October 2009.

ammonium on a Wescan ammonia analyzer, and total $\mathrm{P}$ concentration was measured spectrophotometrically after acidified ammonium persulfate digestion (Anderson and Ingram, 1989). Soil available $P$ was measured spectrophotometrically after extraction with an acid-ammonium fluoride solution (Liu, 1996). Soil $\mathrm{NH}_{4}^{+}-\mathrm{N}$ was measured spectrophotometrically by the indophenol blue method after extraction with a potassium chloride solution (Liu, 1996).

The soil nitrification rate was measured according to the in situ incubation method described by Raison et al. (1987). Briefly, 10 soil cores $(2.5 \mathrm{~cm}$ inner diameter) were collected from each plot, 5 of which were brought to the laboratory for measurement of soil $\mathrm{NO}_{3}^{-}-\mathrm{N}$ using cadmium reduction followed by sulfanilamide-NAD reaction, and the remainders were returned to the plots for 1 month incubation. The nitrification rate was calculated from the difference between extractable $\mathrm{NO}_{3}^{-}-\mathrm{N}$ contents before and after incubation.

\subsection{Statistical analyses}

Repeated-measures analysis of variance was used to examine the effect of fertilizer treatments on soil $\mathrm{N}_{2} \mathrm{O}$ emission and soil properties from February 2007 to October 2009. Twoway ANOVA was used to determine the treatment effects on soil $\mathrm{N}_{2} \mathrm{O}$ emission. One-way ANOVA was used to determine the differences in soil properties among treatments for each sampling. Linear regression analyses were used to determine the relationships between $\mathrm{N}_{2} \mathrm{O}$ emission and soil WFPS or soil temperature in each forest. Data were tested for normality (Kolmogorov-Smirnov test) and equality (Levene's test) of variances and were log-transformed for analysis if they did not meet the requirements of normality or equality of variances. All analyses were conducted using the SPSS 16.0 for windows (SPSS Inc., Chicago, IL, USA). Statistically significant differences were recognized at $P<0.05$, unless otherwise stated.

\section{Results}

\subsection{Soil temperature}

Soil temperature (at $5 \mathrm{~cm}$ depth) showed a similar pattern in all plots across the three forests, increasing from spring to summer and decreasing from fall to winter (Fig. 1). The mean soil temperature of the control plots during the study period was $21.8 \pm 0.4,22.6 \pm 0.4$, and $23.4 \pm 0.4^{\circ} \mathrm{C}$ in the old-growth, mixed, and pine forests, respectively. Repeated-measures ANOVA highlighted significant differences $(P<0.001)$ in soil temperatures between each forest. In the mixed forest, soil temperature was significantly lower in $\mathrm{P}$-addition plots $(P=0.043$ ) compared to the control plots, while $\mathrm{N}$ and NP addition had no effect on soil temperature. No treatment effect was detected on soil tem- 


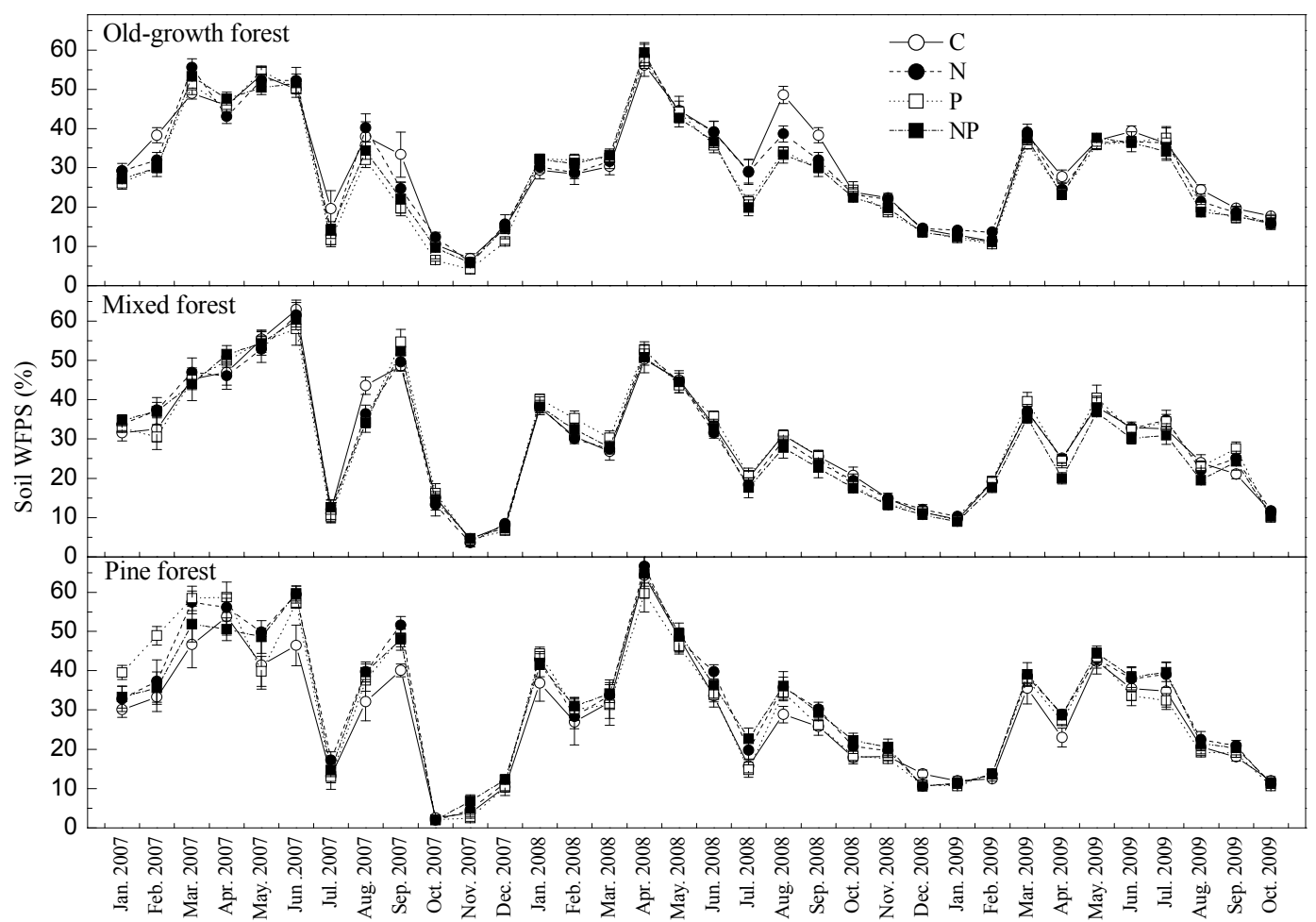

Figure 2. Monthly soil WFPS in the three study forests of Dinghushan Biosphere Reserve (DHSBR) from January 2007 to October 2009.

perature in the old-growth and pine forests, as determined by repeated-measures ANOVA.

\subsection{Soil WFPS}

Soil WFPS $(0-10 \mathrm{~cm}$ depth) increased in all forests from dry winter to wet spring but decreased in summer, possibly due to the higher plant uptake and transpiration, despite the high amount of precipitation in summer (Fig. 2). Mean soil WFPS in control plots during the study period was $31.1 \pm 1.1,29.5 \pm 1.2$, and $28.3 \pm 1.2 \%$ in the old-growth, mixed, and pine forests, respectively. Repeated-measures ANOVA showed no significant difference of soil WFPS in the control plots among three forests. N, P, and NP addition had no significant effect on soil WFPS in any forest, as determined by repeated-measures ANOVA.

\subsection{Soil properties}

Repeated-measures ANOVA showed that soil $\mathrm{pH}$ significantly increased after $\mathrm{P}$ addition in the old-growth forest (Table 2). Soil $\mathrm{NO}_{3}^{-}$concentrations significantly decreased after $\mathrm{P}$ addition in the old-growth and mixed forests and significantly increased after $\mathrm{N}$ addition in the pine forest. Soil $\mathrm{NH}_{4}^{+}$ concentrations and total inorganic $\mathrm{N}\left(\mathrm{NH}_{4}^{+}+\mathrm{NO}_{3}^{-}\right)$concentrations had no response to either $\mathrm{N}$ or $\mathrm{P}$ addition in any forest. Soil available $\mathrm{P}$ concentrations significantly increased after $\mathrm{P}$ addition in all the forests. Soil organic $\mathrm{C}$ significantly increased after $\mathrm{N}$ addition in the mixed and pine forests but not in the old-growth forest. Soil microbial biomass $\mathrm{C}$ significantly increased after $\mathrm{P}$ addition in the old-growth forest and after $\mathrm{N}$ addition in the mixed forest. Interaction of combined $\mathrm{N}$ and $\mathrm{P}$ additions occurred in soil available $\mathrm{P}$ concentrations and microbial biomass $\mathrm{C}$ in the old-growth forest and in soil $\mathrm{pH}$ and $\mathrm{NO}_{3}^{-}$concentrations in the mixed forest.

\subsection{Soil $\mathrm{N}_{2} \mathrm{O}$ emission in control plots}

Soil $\mathrm{N}_{2} \mathrm{O}$ emission was higher in all forests during spring and summer and lower in fall and winter (Fig. 3). Mean soil $\mathrm{N}_{2} \mathrm{O}$ emission was $14.0 \pm 0.7,9.9 \pm 0.4$, and $10.9 \pm 0.5 \mu \mathrm{g} \mathrm{N} \mathrm{N}_{2} \mathrm{O}-$ $\mathrm{N} \mathrm{m}^{-2} \mathrm{~h}^{-1}$ in the old-growth, mixed, and pine forests, respectively (Fig. 4), being significantly higher in the oldgrowth forest than in the mixed $(P=0.001)$ and pine $(P=0.005)$ forests. In the control plots, soil temperature and WFPS showed a significant positive linear relationship with soil $\mathrm{N}_{2} \mathrm{O}$ emission (Fig. 5) and explained 9-17 and 12-23\% of $\mathrm{N}_{2} \mathrm{O}$ fluxes variation across the forests (Table 4). The models that included soil temperature and WFPS as parameters showed the higher $R^{2}$ values (22-28\%; Table 4 ).

\subsection{Soil $\mathrm{N}_{2} \mathrm{O}$ emission after $\mathrm{N}$ and $\mathrm{P}$ addition}

Effects of $\mathrm{N}$ and $\mathrm{P}$ addition on soil $\mathrm{N}_{2} \mathrm{O}$ emission varied with forest type (Fig. 4). In the old-growth forest, mean $\mathrm{N}_{2} \mathrm{O}$ emission during the study period was 
Table 2. Effects of $\mathrm{N}$ and $\mathrm{P}$ addition on soil properties in the three study forests.

\begin{tabular}{|c|c|c|c|c|c|c|c|c|}
\hline \multicolumn{2}{|c|}{ Statistical analyses } & \multirow[b]{2}{*}{$\mathrm{C}$} & \multirow[b]{2}{*}{$\mathrm{N}$} & \multirow[b]{2}{*}{$\mathrm{P}$} & \multirow[b]{2}{*}{ NP } & \multicolumn{3}{|c|}{$\begin{array}{c}\text { Repeated-measures } \\
\text { ANOVA }\end{array}$} \\
\hline & Treatment & & & & & $\mathrm{N}$ & $\mathrm{P}$ & $\mathrm{N} \times \mathrm{P}$ \\
\hline \multirow{7}{*}{$\begin{array}{l}\text { Old-growth } \\
\text { forest }\end{array}$} & $\mathrm{pH}$ & $3.9(0.0)$ & $3.9(0.0)$ & $4.0(0.0)$ & $3.9(0.0)$ & ns & $* *$ & ns \\
\hline & $\mathrm{NH}_{4}^{+}\left(\mathrm{mg} \mathrm{kg}^{-1}\right)$ & $8.7(0.8)$ & $10.1(0.9)$ & $9.7(0.8)$ & $10.2(1.2)$ & ns & $\mathrm{ns}$ & ns \\
\hline & $\mathrm{NO}_{3}^{-}\left(\mathrm{mg} \mathrm{kg}^{-1}\right)$ & $5.9(0.6)$ & $6.6(0.8)$ & $4.5(0.8)$ & $3.5(0.5)$ & ns & $* *$ & ns \\
\hline & $\mathrm{NH}_{4}^{+}+\mathrm{NO}_{3}^{-}\left(\mathrm{mg} \mathrm{kg}^{-1}\right)$ & $14.6(1.1)$ & $16.7(1.5)$ & $14.2(1.2)$ & $13.8(1.4)$ & $\mathrm{ns}$ & $\mathrm{ns}$ & ns \\
\hline & Available P $\left(\mathrm{mg} \mathrm{kg}^{-1}\right)$ & $1.4(0.2)$ & $2.7(0.6)$ & $8.7(1.4)$ & $5.8(1.0)$ & ns & $* *$ & $*$ \\
\hline & Soil organic C (\%) & $4.1(0.2)$ & $4.6(0.2)$ & $4.8(0.1)$ & $4.4(0.2)$ & ns & $\mathrm{ns}$ & ns \\
\hline & $\mathrm{MBC}\left(\mathrm{mg} \mathrm{kg}^{-1}\right)$ & $434.3(42.7)$ & $359.9(41.2)$ & $422.6(44.9)$ & $488.6(60.0)$ & ns & $*$ & * \\
\hline \multirow{7}{*}{$\begin{array}{l}\text { Mixed } \\
\text { forest }\end{array}$} & $\mathrm{pH}$ & $4.0(0.0)$ & $4.1(0.0)$ & $4.1(0.0)$ & $4.0(0.0)$ & ns & ns & $*$ \\
\hline & $\mathrm{NH}_{4}^{+}\left(\mathrm{mg} \mathrm{kg}^{-1}\right)$ & $8.4(0.9)$ & $8.9(0.9)$ & $8.9(0.9)$ & $9.0(0.9)$ & ns & $\mathrm{ns}$ & ns \\
\hline & $\mathrm{NO}_{3}^{-}\left(\mathrm{mg} \mathrm{kg}^{-1}\right)$ & $1.9(0.3)$ & $1.8(0.3)$ & $1.2(0.2)$ & $1.8(0.3)$ & ns & $*$ & $* *$ \\
\hline & $\mathrm{NH}_{4}^{+}+\mathrm{NO}_{3}^{-}\left(\mathrm{mg} \mathrm{kg}^{-1}\right)$ & $10.3(1.1)$ & $10.7(1.0)$ & $10.1(1.0)$ & $10.8(1.0)$ & $\mathrm{ns}$ & $\mathrm{ns}$ & ns \\
\hline & Available $\mathrm{P}\left(\mathrm{mg} \mathrm{kg}^{-1}\right)$ & $1.4(0.2)$ & $3.7(0.8)$ & $7.2(1.3)$ & $5.7(1.1)$ & $\mathrm{ns}$ & $* *$ & ns \\
\hline & Soil organic C (\%) & $2.4(0.1)$ & $2.8(0.1)$ & $2.7(0.1)$ & $2.9(0.1)$ & $*$ & ns & ns \\
\hline & $\operatorname{MBC}\left(\mathrm{mg} \mathrm{kg}^{-1}\right)$ & $239.7(23.6)$ & $254.5(25.69)$ & $240.5(31.9)$ & $291.5(31.8)$ & $*$ & ns & ns \\
\hline \multirow{7}{*}{ Pine forest } & $\mathrm{pH}$ & $4.0(0.0)$ & $4.0(0.0)$ & $4.0(0.0)$ & $4.0(0.0)$ & $\mathrm{ns}$ & $\mathrm{ns}$ & ns \\
\hline & $\mathrm{NH}_{4}^{+}\left(\mathrm{mg} \mathrm{kg}^{-1}\right)$ & $8.8(0.7)$ & $8.5(1.0)$ & $8.3(0.9)$ & $8.9(1.1)$ & $\mathrm{ns}$ & ns & ns \\
\hline & $\mathrm{NO}_{3}^{-}\left(\mathrm{mg} \mathrm{kg}^{-1}\right)$ & $2.9(0.4)$ & $3.2(0.4)$ & $2.3(0.4)$ & $3.2(0.4)$ & $*$ & $\mathrm{~ns}$ & ns \\
\hline & $\mathrm{NH}_{4}^{+}+\mathrm{NO}_{3}^{-}\left(\mathrm{mg} \mathrm{kg}^{-1}\right)$ & $11.7(1.0)$ & $11.7(1.2)$ & $10.6(1.1)$ & $12.1(1.2)$ & ns & $\mathrm{ns}$ & ns \\
\hline & Available P $\left(\mathrm{mg} \mathrm{kg}^{-1}\right)$ & $1.9(0.4)$ & $1.5(0.4)$ & $7.7(1.4)$ & $7.2(1.4)$ & ns & $* *$ & ns \\
\hline & Soil organic C (\%) & $3.3(0.1)$ & $3.6(0.2)$ & $3.4(0.1)$ & $3.9(0.2)$ & $*$ & ns & ns \\
\hline & $\operatorname{MBC}\left(\mathrm{mg} \mathrm{kg}^{-1}\right)$ & $306.2(41.1)$ & $274.3(40.7)$ & $260.2(33.1)$ & $268.2(34.7)$ & ns & $\mathrm{ns}$ & ns \\
\hline
\end{tabular}

Notes: soils were sampled in August 2007, February 2008, August 2008, February 2009, and August 2009. February and August are within the dry and wet season, respectively, in the study region. Values shown in Table 2 are means (all sampling periods) with standard error in parentheses ( $n=25)$, and the values of each sampling period are shown in Tables S2-S4 in the Supplement. MBC: microbial biomass carbon. "**”, “*”, and "ns" represent statistical difference of $P<0.01$, $P<0.05$, and $P>0.05$, respectively.

Table 3. $P$ value of two-way repeated-measures ANOVA of seasonal $\mathrm{N}_{2} \mathrm{O}$ fluxes in the three study forests.

\begin{tabular}{|c|c|c|c|c|c|c|c|c|c|c|}
\hline Seasons & Spring 2007 & Summer 2007 & Fall 2007 & Winter 2008 & Spring 2008 & Summer 2008 & Fall 2008 & Winter 2009 & Spring 2009 & Summer 2009 \\
\hline \multicolumn{11}{|c|}{ Old-growth forest } \\
\hline $\mathrm{N}$ & 0.001 & 0.470 & 0.048 & 0.021 & 0.631 & 0.761 & 0.029 & 0.253 & 0.567 & 0.775 \\
\hline $\mathrm{P}$ & 0.328 & 0.519 & 0.552 & 0.265 & 0.383 & 0.931 & 0.090 & 0.356 & 0.524 & 0.052 \\
\hline $\mathrm{N} \times \mathrm{P}$ & 0.531 & 0.748 & 0.556 & 0.034 & 0.751 & 0.519 & 0.782 & 0.565 & 0.202 & 0.172 \\
\hline \multicolumn{11}{|c|}{ Mixed forest } \\
\hline $\mathrm{N}$ & 0.881 & 0.667 & 0.253 & 0.017 & 0.304 & 0.866 & 0.609 & 0.446 & 0.989 & 0.349 \\
\hline $\mathrm{P}$ & 0.601 & 0.948 & 0.462 & 0.128 & 0.522 & 0.649 & 0.570 & 0.958 & 0.277 & 0.102 \\
\hline $\mathrm{N} \times \mathrm{P}$ & 0.721 & 0.487 & 0.084 & 0.043 & 0.814 & 0.440 & 0.470 & 0.089 & 0.509 & 0.711 \\
\hline \multicolumn{11}{|c|}{ Pine forest } \\
\hline $\mathrm{N}$ & 0.027 & 0.101 & 0.934 & 0.255 & 0.612 & 0.793 & 0.045 & 0.907 & 0.762 & 0.651 \\
\hline $\mathrm{P}$ & 0.559 & 0.117 & 0.152 & 0.600 & 0.743 & 0.875 & 0.898 & 0.234 & 0.912 & 0.410 \\
\hline $\mathrm{N} \times \mathrm{P}$ & 0.491 & 0.024 & 0.163 & 0.431 & 0.685 & 0.194 & 0.400 & 0.097 & 0.834 & 0.434 \\
\hline
\end{tabular}

Notes: spring from April to June, summer from July to September, fall from October to December, and winter from January to March. $P$ values that are less than 0.1 are marked by bold type.

$24.7 \%$ higher in the $\mathrm{N}$-addition plots $\left(17.4 \pm 1.1 \mu \mathrm{g} \mathrm{N} \mathrm{N}_{2} \mathrm{O}\right.$ $\mathrm{N} \mathrm{m}^{-2} \mathrm{~h}^{-1}$ ), not significantly different in the P-addition plots $\left(14.0 \pm 0.8 \mu \mathrm{g} \mathrm{N} \mathrm{N}_{2} \mathrm{O}-\mathrm{N} \mathrm{m}^{-2} \mathrm{~h}^{-1}\right)$, and $13.9 \%$ higher in the NP-addition plots $\left(15.9 \pm 0.9 \mu \mathrm{g} \mathrm{N} \mathrm{N}_{2} \mathrm{O}-\mathrm{N} \mathrm{m}^{-2} \mathrm{~h}^{-1}\right)$ compared to the control plots $\left(14.0 \pm 0.7 \mu \mathrm{g} \mathrm{N}_{2} \mathrm{O}-\mathrm{N} \mathrm{m}^{-2} \mathrm{~h}^{-1}\right)$. However, significant differences were confined to the $\mathrm{N}$-addition treatment $(P=0.036)$. In the mixed forest, mean $\mathrm{N}_{2} \mathrm{O}$ emission slightly increased by $0.7,8.0$, and $3.9 \%$ after $\mathrm{N}, \mathrm{P}$, and NP addition, respectively. In the pine forest, $\mathrm{N}$ and NP addition slightly increased mean $\mathrm{N}_{2} \mathrm{O}$ emission by 1.1 and $14.7 \%$, respectively, while $\mathrm{P}$ addition marginally decreased mean $\mathrm{N}_{2} \mathrm{O}$ emission by $2.5 \%$. In the mixed and pine forest, 


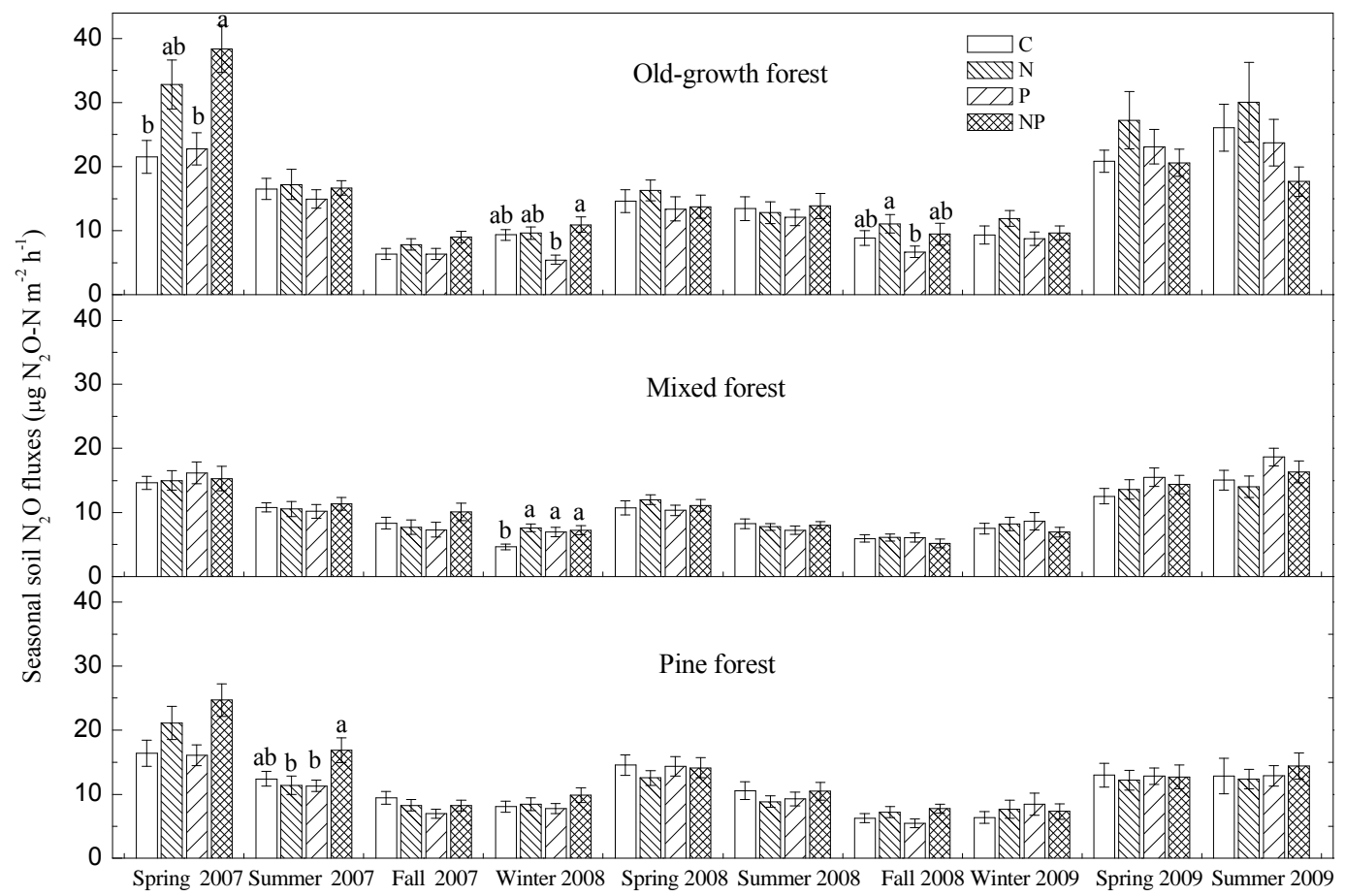

Figure 3. Seasonal variation of $\mathrm{N}_{2} \mathrm{O}$ fluxes in the three study forests during the sampling periods. Each error bar represents standard error of mean $\mathrm{N}_{2} \mathrm{O}$ fluxes from five plots $(n=5)$, and the data of $\mathrm{N}_{2} \mathrm{O}$ fluxes in each plot have been averaged by season (3 months). Different lowercase letters within each season represent significant differences among treatments, as determined by repeated-measures ANOVA $(P<0.05)$.

Table 4. Models for the relationships between $\mathrm{N}_{2} \mathrm{O}$ fluxes $\left(\mathrm{N}_{2} \mathrm{O}\right)$, soil WFPS (W), and temperature $(T)$ in the control plots of the study forests.

\begin{tabular}{lllrrr}
\hline Parameters & Forest type & Regression models & $P$ value & $R^{2}$ & $n$ \\
\hline $\mathrm{N}_{2} \mathrm{O}, \mathrm{W}$ & Old-growth forest & $\mathrm{N}_{2} \mathrm{O}=0.22 \times \mathrm{W}+6.80$ & $<0.001$ & 0.12 & 169 \\
& Mixed forest & $\mathrm{N}_{2} \mathrm{O}=0.13 \times \mathrm{W}+5.77$ & $<0.001$ & 0.18 & 168 \\
& Pine forest & $\mathrm{N}_{2} \mathrm{O}=0.20 \times \mathrm{W}+5.15$ & $<0.001$ & 0.23 & 168 \\
\hline $\mathrm{N}_{2} \mathrm{O}, T$ & Old-growth forest & $\mathrm{N}_{2} \mathrm{O}=0.79 \times T-3.61$ & $<0.001$ & 0.17 & 169 \\
& Mixed forest & $\mathrm{N}_{2} \mathrm{O}=0.32 \times T+2.45$ & $<0.001$ & 0.11 & 168 \\
& Pine forest & $\mathrm{N}_{2} \mathrm{O}=0.39 \times T+1.58$ & $<0.001$ & 0.09 & 169 \\
\hline $\mathrm{N}_{2} \mathrm{O}, \mathrm{W}, T$ & Old-growth forest & $\mathrm{N}_{2} \mathrm{O}=0.64 \times T+0.14 \times \mathrm{W}-4.75$ & $<0.001$ & 0.22 & 169 \\
& Mixed forest & $\mathrm{N}_{2} \mathrm{O}=0.22 \times T+0.11 \times \mathrm{W}+1.53$ & $<0.001$ & 0.22 & 168 \\
& Pine forest & $\mathrm{N}_{2} \mathrm{O}=0.28 \times T+0.18 \times \mathrm{W}-0.86$ & $<0.001$ & 0.28 & 168 \\
\hline
\end{tabular}

no significant differences among treatments were identified by repeated-measures ANOVA.

Two-way ANOVA highlighted the significant positive effects of $\mathrm{N}$ addition on $\mathrm{N}_{2} \mathrm{O}$ emission in spring 2007, fall 2007, winter 2008, and fall 2008 and the marginal negative effects of $\mathrm{P}$ addition in fall 2008 and summer 2009 in the oldgrowth forest (Table 3 ). In contrast, only a significant positive effect of $\mathrm{N}$ addition occurred in winter 2008 in the mixed forest and in spring 2007 and fall 2008 in the pine forest. Interactive effects $(P<0.1)$ of combined $\mathrm{N}$ and $\mathrm{P}$ additions occurred in the old-growth (winter 2008), mixed (fall 2007, winter 2008, and winter 2009), and pine (summer 2007, winter 2009) forests.

\subsection{Soil nitrification rate}

In the old-growth forest, $\mathrm{N}$ addition significantly increased the soil nitrification rate $(P=0.005)$, while $\mathrm{P}$ and NP addition had no significant effect (Fig. 6). In the mixed and pine forest, the soil nitrification rate was not affected by $\mathrm{N}$ and/or $\mathrm{P}$ addition. 


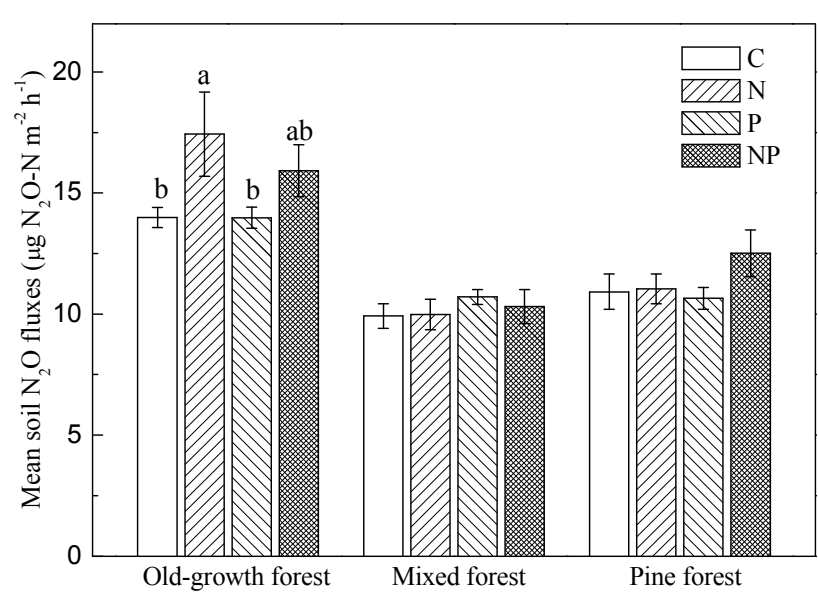

Figure 4. Effects of $\mathrm{N}$ and $\mathrm{P}$ addition on mean soil $\mathrm{N}_{2} \mathrm{O}$ fluxes from February 2007 to October 2009. Each error bar represents standard error of mean $\mathrm{N}_{2} \mathrm{O}$ fluxes from five plots $(n=5)$, and the data of $\mathrm{N}_{2} \mathrm{O}$ fluxes in each plot have been averaged from the whole sampling period (33 months). Different lowercase letters within each forest represent significant differences among treatments, as determined by repeated-measures ANOVA $(P<0.05)$.

\section{Discussion}

\section{1 $\mathrm{N}_{2} \mathrm{O}$ emission in control plots}

Soil $\mathrm{N}_{2} \mathrm{O}$ emissions measured in the present study (9.9$13.9 \mu \mathrm{g} \mathrm{N}_{2} \mathrm{O}-\mathrm{N} \mathrm{m}^{-2} \mathrm{~h}^{-1}$ ) were comparable to previous reports from tropical forests $\left(10.0-11.5 \mu \mathrm{g} \mathrm{N} \mathrm{N}_{2} \mathrm{O}-\mathrm{N} \mathrm{m}^{-2} \mathrm{~h}^{-1}\right.$; Kiese et al., 2008; Sousa Neto et al., 2011). However, our results were lower than those from adjacent forests (24.1-69.0 $\mu \mathrm{g} \mathrm{N} \mathrm{N}_{2} \mathrm{O}-\mathrm{N} \mathrm{m}^{-2} \mathrm{~h}^{-1}$; Tang et al., 2006; Zhang et al., 2008b) and other tropical forests (16.3-77.1 $\mu \mathrm{g} \mathrm{N} \mathrm{N}_{2} \mathrm{O}$ $\mathrm{N} \mathrm{m}^{-2} \mathrm{~h}^{-1}$; Kiese et al., 2008; Davidson et al., 2008; Konda et al., 2010) and higher than those from many tropical or subtropical forests $\left(1.0-8.7 \mu \mathrm{g} \mathrm{N} \mathrm{N}_{2} \mathrm{O}-\mathrm{N} \mathrm{m}^{-2} \mathrm{~h}^{-1}\right.$; Hall et al., 2004; Werner et al., 2006; Wang et al., 2010; Wieder et al., 2011). Taken together, these data suggest a high variation in $\mathrm{N}_{2} \mathrm{O}$ emission among different study regions, possibly due to the difference in soil types and/or climatic conditions.

As expected, a generally higher seasonal $\mathrm{N}_{2} \mathrm{O}$ emission and a significantly higher mean $\mathrm{N}_{2} \mathrm{O}$ emission were identified in the old-growth forest than in the two younger forests (Figs. 3 and 4), suggesting that $\mathrm{N}_{2} \mathrm{O}$ emission may vary depending on forest type. $\mathrm{N}_{2} \mathrm{O}$ emission has been suggested to increase with succession (Verchot et al., 1999; Erickson et al., 2001), possibly due to the increase in soil $\mathrm{N}$ content (Erickson et al., 2002). For example, soil $\mathrm{N}$ enrichment due to the presence of $\mathrm{N}$-fixing legume trees has been linked with higher $\mathrm{N}_{2} \mathrm{O}$ emission (Erickson et al., 2002; Arai et al., 2008; Konda et al., 2010; Zhang et al., 2014). In addition, higher $\mathrm{N}_{2} \mathrm{O}$ emission in $\mathrm{N}$-rich soils has been reported by a study in adjacent forests with different soil $\mathrm{N}$ status (Zhang et al., 2008b). These findings are consistent with our
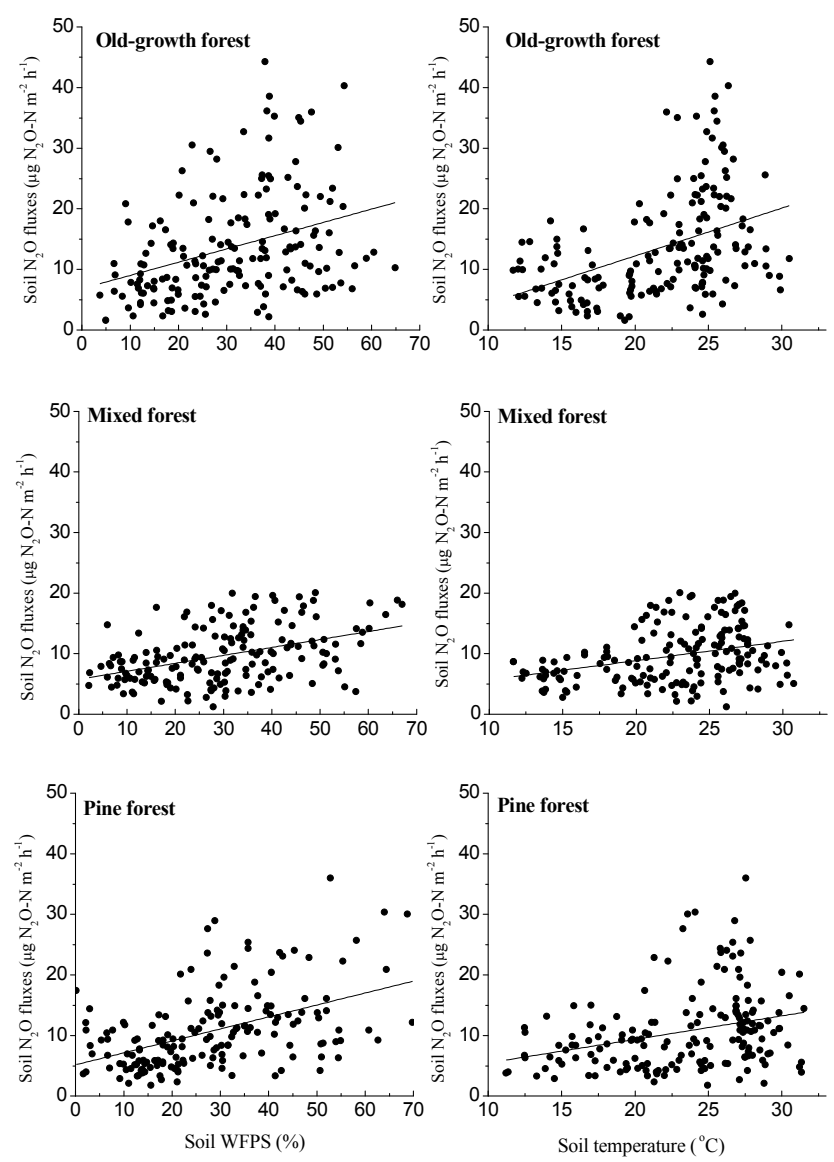

Figure 5. Relationships between $\mathrm{N}_{2} \mathrm{O}$ fluxes and soil WFPS (and temperature) in the five control plots of the study forests, as determined by linear regression analyses. Coefficients of the regression lines are listed in Table 4.

results in that the old-growth forest had higher inorganic $\mathrm{N}$ $\left(\mathrm{NH}_{4}^{+}\right.$and $\left.\mathrm{NO}_{3}^{-}\right)$and total $\mathrm{N}$ content than the mixed and pine forests (Table 1). Given almost complete saturation of $\mathrm{N}$ in this old-growth forest, investigated previously by Fang et al. (2008), excess $\mathrm{N}$ in soils would be readily lost as dissolved organic and inorganic $\mathrm{N}$ (Fang et al., 2008, 2009) and $\mathrm{N}_{2} \mathrm{O}$ gas (Zhang et al., 2008b). Thus, our results further confirm that $\mathrm{N}$-rich forests have a higher $\mathrm{N}_{2} \mathrm{O}$ emission than $\mathrm{N}-$ limited forests.

In addition to soil $\mathrm{N}$ status, soil $\mathrm{pH}$ and the availability of other nutrients may account for higher $\mathrm{N}_{2} \mathrm{O}$ emission in the old-growth forest. Compared to the younger forests, the oldgrowth forest had more acid soil conditions (Tables 1 and 2), likely supporting the higher chemo-denitrification (Tate, 1995; Chalk and Smith, 1983; Mørkved et al., 2007). Additionally, the old-growth forest had significantly higher soil dissolved organic $\mathrm{C}$ and total organic $\mathrm{C}$ (Table 1), which could provide more $\mathrm{C}$ energy for $\mathrm{N}_{2} \mathrm{O}$ production (Zhang et al., 2014). N-rich and P-limiting conditions have also been suggested to support higher $\mathrm{N}_{2} \mathrm{O}$ emission (Zhang et al., 


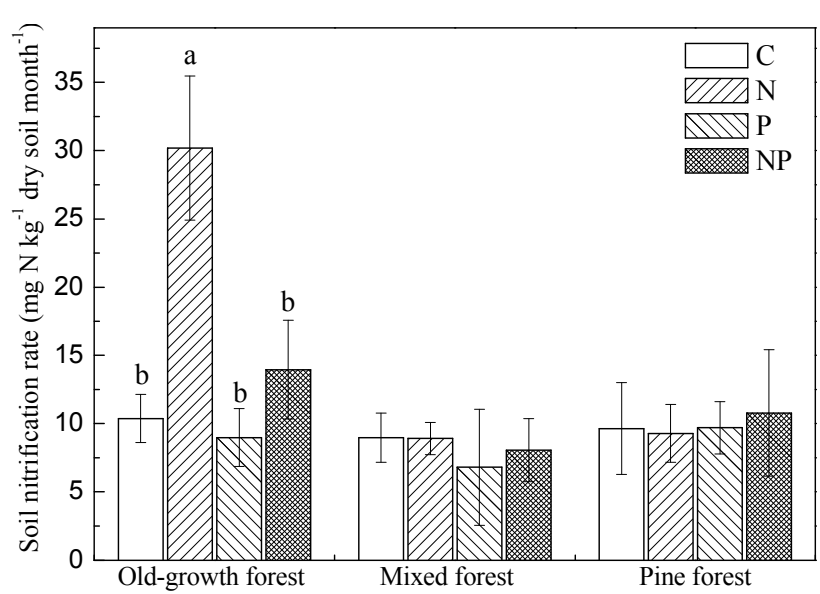

Figure 6. Effects of $\mathrm{N}$ and $\mathrm{P}$ addition on soil nitrification rate in the three study forests in August 2008. Error bars represent standard errors $(n=5)$. Different lowercase letters within each forest represent significant differences among treatments, as determined by one-way ANOVA $(P<0.05)$.

2008b). In the present study, soil $\mathrm{N}: \mathrm{P}$ ratios were significantly higher in the old-growth forest than in the mixed and pine forest (Table 1), suggesting that the low availability of soil $\mathrm{P}$ may intensify $\mathrm{N}_{2} \mathrm{O}$ emission under $\mathrm{N}$-rich conditions (Zhang et al., 2014), thus indicating the potential interaction of $\mathrm{N}$ and $\mathrm{P}$ to control $\mathrm{N}_{2} \mathrm{O}$ emission.

\subsection{Effects of soil temperature and WFPS on $\mathrm{N}_{2} \mathrm{O}$ emission}

Overall, soil temperature increased from spring to summer but decreased from fall to winter in all the forest plots (Fig. 1). $\mathrm{N}_{2} \mathrm{O}$ emission was positively correlated to soil temperature in all three forests (Table 4 and Fig. 5), which was consistent with previous studies in tropical forests (Butterbach-Bahl et al., 2004; Zhang et al., 2008b; Zhu et al., 2013b; Zhang et al., 2014). However, mean soil temperature was highest in the pine forest, followed by the mixed and old-growth forests (statistical difference of $P<0.001$ between each forest), which was inconsistent with the patterns of mean $\mathrm{N}_{2} \mathrm{O}$ emission identified across forests (being significantly higher in the old-growth forest than in the mixed $(P=0.001)$ and pine ( $P=0.005)$ forests; Fig. 4$)$. This suggests a limited ability of soil temperature to explain the pattern in $\mathrm{N}_{2} \mathrm{O}$ emission across forests with different soil $\mathrm{N}$ status.

Compared to the models with soil temperature and $\mathrm{N}_{2} \mathrm{O}$ fluxes as parameters, the $R^{2}$ values of the models with soil WFPS and $\mathrm{N}_{2} \mathrm{O}$ fluxes as parameters were not much higher (Table 4). However, mean soil WFPS showed comparable dynamics to mean $\mathrm{N}_{2} \mathrm{O}$ emission, with the highest WFPS in the old-growth forest and the lowest WFPS in the pine forest (Fig. 2). In each forest, soil WFPS showed a positive relationship with $\mathrm{N}_{2} \mathrm{O}$ emission (Fig. 5), as has previously been observed across forests with different soil $\mathrm{N}$ status (Zhang et al., 2008b, 2014). Moreover, seasonal patterns in soil WFPS (Fig. 2) and $\mathrm{N}_{2} \mathrm{O}$ emission were comparable in all forests (Fig. 3), suggesting that soil WFPS can predict the seasonal variance of $\mathrm{N}_{2} \mathrm{O}$ emission, as follows. In spring, forest soil was enriched with inorganic $\mathrm{N}$ (accumulated during nongrowing seasons mainly due to the lack of rainfall; Mo et al., 2003) and had higher WFPS (increased in wet seasons), conditions that would generate a pulsing effect because wetting dry soil will trigger emissions of $\mathrm{N}_{2} \mathrm{O}$ and other nitrogenous gases by stimulating microbial consumption of soil $\mathrm{NH}_{4}^{+}$ and/or $\mathrm{NO}_{3}^{-}$(Davidson et al., 2000; Butterbach-Bahl et al., 2004; Werner et al., 2006). In summer, $\mathrm{N}_{2} \mathrm{O}$ emission began to decrease given decreasing soil WFPS (Fig. 3) possibly caused by the higher plant uptake and transpiration (Cheng et al., 2015). In fall and winter, both the lower soil inorganic $\mathrm{N}$ (decreased after growing seasons; Mo et al., 2003) and WFPS (decreased in dry seasons) suppressed $\mathrm{N}_{2} \mathrm{O}$ production. Accordingly, $\mathrm{N}_{2} \mathrm{O}$ emission was highest in spring, declined in summer, and was lowest in fall and winter (Fig. 3). Thus, our findings suggest that soil WFPS may be a more appropriate predictor of $\mathrm{N}_{2} \mathrm{O}$ emission in forests with different soil $\mathrm{N}$ status than soil temperature.

\subsection{Effects of $\mathrm{N}$ addition on $\mathrm{N}_{2} \mathrm{O}$ emission}

As expected, $\mathrm{N}$ addition significantly increased mean $\mathrm{N}_{2} \mathrm{O}$ emission in the old-growth forest but not in the mixed and pine forests (Fig. 4), which was consistent with the results from adjacent forests (Zhang et al., 2008b). In several N-rich forests, $\mathrm{N}_{2} \mathrm{O}$ emission significantly increased after $\mathrm{N}$ addition (Hall and Matson, 1999; Venterea et al., 2003; Koehler et al., 2009; Zhang et al., 2014), whereas it was hardly impacted by $\mathrm{N}$ input in the N-limited forests (Davidson et al., 2000; Skiba et al., 2004) or only increased after chronic N addition (Magill et al., 2000; Hall and Matson, 2003). This indicates an important control of $\mathrm{N}_{2} \mathrm{O}$ emission by soil $\mathrm{N}$ status (Zhang et al., 2008b), as explained below.

As supported by our results, additional $\mathrm{N}$ inputs to N-rich forests exceed the ecosystems capacity for $\mathrm{N}$ retention, and thus less $\mathrm{N}$ is utilized (Aber et al., 1998). In the old-growth forest, we found no increase in soil organic $\mathrm{C}$, microbial biomass $\mathrm{C}$ (Table 2) or litter decomposition rate (Mo et al., 2006) after $\mathrm{N}$ addition, whereas live fine-root biomass was shown to decrease (Zhu et al., 2013a), suggesting that $\mathrm{N}$ addition no longer increases soil and plant $\mathrm{C}$ pools in this forest. Moreover, the $\mathrm{N}$ fertilizer application rate was much larger than the atmospheric $\mathrm{N}$ deposition rate, leading to excess soil $\mathrm{N}$ accumulating in the old-growth forest, which would favor nitrifying and denitrifying bacteria (Zhang et al., 2008b) and therefore significantly stimulate soil nitrification rate (Fig. 6), $\mathrm{N}_{2} \mathrm{O}$ emission (Fig. 4), and $\mathrm{NO}_{3}^{-}$leaching (Fang et al., 2009). As a result, no significant increase in soil inorganic $\mathrm{N}\left(\mathrm{NH}_{4}^{+}\right.$ and $\mathrm{NO}_{3}^{-}$) was observed after $\mathrm{N}$ addition in the old-growth forest (Table 2). Thus, in combination with previous findings, 
our results confirm that $\mathrm{N}$ addition will increase $\mathrm{N}_{2} \mathrm{O}$ emission in N-rich forests.

In contrast, in $\mathrm{N}$-limited forests, $\mathrm{N}$ is retained to support plant and microbial growth and/or the accumulation of soil organic matter (Aber et al., 1998; Harrington et al., 2001). In the mixed and pine forests, two N-limited ecosystems (Mo et al., 2006), despite no significant increase in soil total inorganic $\mathrm{N}$ following $\mathrm{N}$ addition, a significant increase in soil microbial biomass $\mathrm{C}$ and soil organic $\mathrm{C}$ was observed in the mixed forest, as well as a significant increase in soil organic $\mathrm{C}$ in the pine forest (Table 2). Both forests showed positive responses of litter decomposition rate to $\mathrm{N}$ addition (Mo et al., 2006), but no net $\mathrm{N}$ losses via $\mathrm{NO}_{3}^{-}$leaching (Fang et al., 2008). In addition, our previous study showed that under atmospheric $\mathrm{N}$ deposition, the $\mathrm{N}$ retention in the two forests was in accordance with the estimates of $\mathrm{N}$ accumulation in plant biomass and litter increment (Mo et al., 2004, 2007a; Fang et al., 2008), suggesting that the $\mathrm{N}$ retention was mainly used for plant growth rather than gaseous $\mathrm{N}$ loss. In this study, although we did not measure other gas losses (such as $\mathrm{NH}_{3}, \mathrm{NO}, \mathrm{HONO}$, and $\mathrm{NO}_{2}$ ), which are also important in forest soils, we found that $\mathrm{N}_{2} \mathrm{O}$ emission showed no response to $\mathrm{N}$ addition in either forest (Fig. 4), and the nitrification rate did not change (Fig. 6). Although rates of $\mathrm{N}$ addition in the present study were much higher than atmospheric $\mathrm{N}$ deposition, all the evidence above suggests that $\mathrm{N}$ continues to be utilized rather than that it is emitted via $\mathrm{N}_{2} \mathrm{O}$ gases following $\mathrm{N}$ addition in our $\mathrm{N}$-limited forests. Further studies are needed to examine whether $\mathrm{N}$ addition increases other nitrogenous gas loss in the $\mathrm{N}$-limited forests.

\subsection{Effects of $\mathrm{P}$ addition on $\mathrm{N}_{2} \mathrm{O}$ emission}

No significant change in mean $\mathrm{N}_{2} \mathrm{O}$ emission was observed following $\mathrm{P}$ addition in any of the study forests (Fig. 4), allowing us to reject the hypothesis that $\mathrm{P}$ addition causes a greater decrease in $\mathrm{N}_{2} \mathrm{O}$ emission in the old-growth forest than in two younger forests. This finding was inconsistent with many previous studies conducted in situ (Mori et al., 2014; Zhang et al., 2014) or in laboratories (Sundareshwar et al., 2003; Mori et al., 2010, 2013; Baral et al., 2014). For example, Mori et al. (2014) and Zhang et al. (2014) reported that $\mathrm{P}$ addition significantly decreased $\mathrm{N}_{2} \mathrm{O}$ emission in a leguminous and non-leguminous plantation. Under laboratory conditions, Sundareshwar et al. (2003) found a negative response of sediment $\mathrm{N}_{2} \mathrm{O}$ emission to phosphate addition. Based on a pot experiment with maize, Baral et al. (2014) also suggested that alleviation of $\mathrm{P}$ limitation would decrease $\mathrm{N}_{2} \mathrm{O}$ emission. The major mechanism of this P-driven decrease in $\mathrm{N}_{2} \mathrm{O}$ emission is the increased plant uptake of soil $\mathrm{N}$ due to higher $\mathrm{P}$ availability, which therefore reduces $\mathrm{N}$ availability for nitrifying and denitrifying bacteria (Mori et al., 2010). However, several incubation experiments found a positive response of $\mathrm{N}_{2} \mathrm{O}$ emission to $\mathrm{P}$ addition (Mori et al., 2010, 2013), with authors suggesting that $\mathrm{P}$ addition might stimulate soil $\mathrm{N}$ cycles for nitrification and denitrification and/or might alleviate soil $\mathrm{P}$ limitation of nitrifying and denitrifying bacteria. In contrast, a lack of response of $\mathrm{N}_{2} \mathrm{O}$ emission to $\mathrm{P}$ addition has rarely been reported, especially for natural forests (Wang et al., 2014), and the mechanism remains poorly understood.

Based on the present study, we propose that a lack of response of $\mathrm{N}_{2} \mathrm{O}$ emission to $\mathrm{P}$ addition may be attributed to failure of soil $\mathrm{N}$ immobilization or $\mathrm{N}$ uptake stimulated by the short-term $\mathrm{P}$ addition. $\mathrm{P}$ fertilization has been suggested to decrease soil $\mathrm{N}$ substrates (or increase soil $\mathrm{N}$ immobilization) and thus suppress $\mathrm{N}_{2} \mathrm{O}$ production (Sundareshwar et al., 2003; Mori et al., 2010, 2014; Zhang et al., 2014). However, we found no significant change in soil total inorganic $\mathrm{N}$ $\left(\mathrm{NH}_{4}^{+}\right.$plus $\left.\mathrm{NO}_{3}^{-}\right)$after $\mathrm{P}$ addition in all forests, despite a significant decrease in $\mathrm{NO}_{3}^{-}$in the old-growth and mixed forests (Table 2). Moreover, the soil nitrification rate remained stable after $\mathrm{P}$ addition in all forests (Fig. 6), suggesting that $\mathrm{P}$ addition did not affect $\mathrm{N}_{2} \mathrm{O}$ production in the present study. Yet, in a recent study, significant decreases in soil inorganic $\mathrm{N}$ and $\mathrm{N}_{2} \mathrm{O}$ emission occurred after 6 years of $\mathrm{P}$ addition in an old-growth forest (Chen et al., 2015), indicating that $\mathrm{N}_{2} \mathrm{O}$ emission may remain stable following short-term $\mathrm{P}$ addition but decrease after long-term addition in N-rich forests. We further suggest studies to identify whether long-term $\mathrm{P}$ addition will also decrease $\mathrm{N}_{2} \mathrm{O}$ emission in $\mathrm{N}$-limited forests.

\subsection{Effects of combined $\mathrm{N}$ and $\mathrm{P}$ additions on $\mathrm{N}_{2} \mathrm{O}$ emission}

Consistent with our hypothesis, mean $\mathrm{N}_{2} \mathrm{O}$ emission showed no response to combined $\mathrm{N}$ and $\mathrm{P}$ additions in all forests (Fig. 4), suggesting that $\mathrm{P}$ alleviated the stimulating effect of $\mathrm{N}$ addition on $\mathrm{N}_{2} \mathrm{O}$ emission in the old-growth forest, as has been reported by several previous studies. For example, Hall and Matson (2003) reported that $\mathrm{N}$ addition significantly increased soil $\mathrm{N}_{2} \mathrm{O}$ emission but $\mathrm{N}$ and $\mathrm{P}$ addition had no effect in a P-limited forest. Using a pot experiment, Baral et al. (2014) found that $\mathrm{N}_{2} \mathrm{O}$ emission was highest under $\mathrm{N}$ fertilization treatment but reduced after $\mathrm{P}$ fertilization in a P-limited soil-sand mixture. Zhang et al. (2014) also reported that $\mathrm{N}_{2} \mathrm{O}$ emission significantly increased with $\mathrm{N}$ addition but not with NP addition in a leguminous plantation. However, our results were inconsistent with those of Mori et al. (2013) and Wang et al. (2014), who suggested that both $\mathrm{N}$ and $\mathrm{NP}$ addition significantly increased $\mathrm{N}_{2} \mathrm{O}$ emission.

Currently, two mechanisms of the $\mathrm{P}$ alleviation of $\mathrm{N}_{2} \mathrm{O}$ emission are plausible. First, $\mathrm{P}$ addition may alleviate $\mathrm{P}$ limitation of plants and thus increase plant uptake of $\mathrm{N}$ (Hall and Matson, 1999; Baral et al., 2014; Sundareshwar et al., 2003). Second, $P$ addition may alleviate $P$ limitation of soil microbes and therefore increase microbial $\mathrm{N}$ immobilization (Sundareshwar et al., 2003). Both pathways will reduce soil $\mathrm{N}$ substrates available for $\mathrm{N}_{2} \mathrm{O}$ production. Although plant and microbial $\mathrm{N}$ contents were not measured in this study, 
our recent study in the old-growth forest found no effect of 5 years of $\mathrm{P}$ and NP addition on fine-root $\mathrm{N}$ contents (Zhu et al., 2013a). $P$ addition likely alleviated the $P$ limitation on soil microbes in our old-growth forest because our previous study showed that $\mathrm{P}$ addition significantly increased soil microbial biomass and soil respiration (Liu et al., 2012). Compared with the controls, $\mathrm{P}$ addition changed soil microbial community, including the increases in biomass of bacteria and arbuscular mycorrhizal (AM) fungi (Liu et al., 2012, 2013). The increases in AM fungi may help plants acquire more $\mathrm{N}$ and $\mathrm{P}$ nutrients (Tresede and Vitousek, 2001) because they are more efficient in obtaining nutrients from the soil than the plant roots (Liu et al., 2013). In addition, the increases in bacterial and fungal biomass may potentially increase total $\mathrm{N}$ acquirement, as evidenced by our previous study showing that 4 years of $\mathrm{P}$ and NP addition tended to increase soil microbial biomass $\mathrm{N}$ (Liu et al., 2013). Accordingly, P alleviation of the $\mathrm{N}$ stimulation on $\mathrm{N}_{2} \mathrm{O}$ emission in our old-growth forest was likely attributed to an increase in microbial $\mathrm{N}$ immobilization. NP addition did not significantly affect soil total inorganic $\mathrm{N}\left(\mathrm{NH}_{4}^{+}\right.$plus $\mathrm{NO}_{3}^{-}$; Table $\left.\mathrm{S} 2\right)$ and thus the soil nitrification rate (Fig. 6), which in turn did not affect $\mathrm{N}_{2} \mathrm{O}$ emission.

It is interesting that the soil $\mathrm{N}_{2} \mathrm{O}$ emission reduced after $\mathrm{P}$ addition compared with that after $\mathrm{N}$ addition (150 $\mathrm{kg} \mathrm{Nha}^{-1} \mathrm{yr}^{-1}$ ) but not when compared with that under atmospheric $\mathrm{N}$ deposition $\left(\sim 50 \mathrm{~kg} \mathrm{Nha}^{-1} \mathrm{yr}^{-1}\right)$. We infer that this may be related to the levels of $\mathrm{N}$ addition and/or the period of $\mathrm{P}$ addition. First, it is possible that low $\mathrm{N}$ addition, such as atmospheric $\mathrm{N}$ deposition in our study, may not cause a significant increase in soil $\mathrm{N}_{2} \mathrm{O}$ emission in this $\mathrm{N}$-rich forest. Our previous study showed that under atmospheric $\mathrm{N}$ deposition (49.5 $\mathrm{kg} \mathrm{Nha}^{-1} \mathrm{yr}^{-1}$ ), soil had higher $\mathrm{N}$ leaching $\left(59.8 \mathrm{~kg} \mathrm{Nha}^{-1} \mathrm{yr}^{-1}\right)$ in this N-rich forest, suggesting a net $\mathrm{N}$ loss under atmospheric $\mathrm{N}$ deposition (low $\mathrm{N}$ input) and thus less $\mathrm{N}$ retained for $\mathrm{N}_{2} \mathrm{O}$ production (Fang et al., 2008). Accordingly, it is possible that low $\mathrm{N}$ addition failed to increase soil $\mathrm{N}_{2} \mathrm{O}$ emission in the $\mathrm{N}$-rich forest, and thus $\mathrm{P}$ addition may show no alleviated effect. Second, a lack of response of $\mathrm{N}_{2} \mathrm{O}$ emission to $\mathrm{P}$ addition compared with the control may also be related to the $\mathrm{P}$ fertilization period. Nutrient ( $\mathrm{N}$ and $\mathrm{P}$ ) addition in our study was only applied for about 2 years, and we did not observe the alleviated effect of $\mathrm{P}$ addition on soil $\mathrm{N}_{2} \mathrm{O}$ emission under atmospheric $\mathrm{N}$ deposition (Figs. 3 and 4). However, our recent study in the same forest found that long-term (6 years) $\mathrm{P}$ addition significantly decreased soil $\mathrm{N}_{2} \mathrm{O}$ emission compared with the control (atmospheric $\mathrm{N}$ deposition; Chen et al., 2015). This suggests that the fertilization period is also an important factor affecting the alleviated effect of $\mathrm{P}$ addition on $\mathrm{N}_{2} \mathrm{O}$ emission in this $\mathrm{N}$-rich forest. Therefore, our findings suggest that $\mathrm{P}$ addition will alleviate the stimulating effects of $\mathrm{N}$ on $\mathrm{N}_{2} \mathrm{O}$ emission in the N-rich forest, but this effect may only occur under high $\mathrm{N}$ addition and/or long-term $\mathrm{P}$ addition.

\section{Conclusions}

To our knowledge, this is the first study to examine how $\mathrm{N}$ and $\mathrm{P}$ interact to control soil $\mathrm{N}_{2} \mathrm{O}$ emission in tropical forests with different soil $\mathrm{N}$ status. Our results confirm that $\mathrm{N}$-rich forests have higher $\mathrm{N}_{2} \mathrm{O}$ emission than $\mathrm{N}$-limited forests, and $\mathrm{N}$ addition will merely increase $\mathrm{N}_{2} \mathrm{O}$ emission in $\mathrm{N}$-rich forests, as less $\mathrm{N}$ is utilized in $\mathrm{N}$-rich soils. However, neither $\mathrm{P}$ nor NP addition affects $\mathrm{N}_{2} \mathrm{O}$ emission in both $\mathrm{N}$-rich and $\mathrm{N}$-limited forests, which suggests that $\mathrm{P}$ addition potentially alleviates $\mathrm{N}$ stimulation of $\mathrm{N}_{2} \mathrm{O}$ emission in $\mathrm{N}$-rich forests, with the potential mechanism of microbial $\mathrm{N}$ immobilization, but this alleviated effect may only occur under high $\mathrm{N}$ addition and/or long-term $\mathrm{P}$ addition. Therefore, $\mathrm{P}$ fertilization can be used to reduce soil $\mathrm{N}_{2} \mathrm{O}$ emission in $\mathrm{N}$-rich forests under atmospheric $\mathrm{N}$ deposition, but we suggest more investigations to definitively assess this management strategy and the importance of $\mathrm{P}$ in regulating $\mathrm{N}$ cycles from regional to global scales.

\section{The Supplement related to this article is available online at doi:10.5194/bg-13-3503-2016-supplement.}

Acknowledgements. This study was financially supported by the National Natural Science Foundation of China (no: 41273143 and 41473112), the Natural Science Foundation of Guangdong Province (2014A030311023) and the Research Fund for the Doctoral Program of Lingnan Normal University (ZL 1202). We thank four anonymous referees for their comments and suggestions on the manuscript.

Edited by: I. Trebs

\section{References}

Aber, J., McDowell, W., Nadelhoffer, K., Magill, A., Berntson, G., Kamakea, M., McNulty, S., Currie, W., Rustad, L., and Fernandez, I.: Nitrogen saturation in temperate forest ecosystemsHypotheses revisited, Bioscience, 48, 921-934, 1998.

Aber, J. D., Nadelhoffer, K. J., Steudler, P., and Melillo, J. M.: Nitrogen saturation in northern forest ecosystems, BioScience, 39, 378-286, 1989.

Anderson, J. and Ingram, J.: Tropical soil biology and fertility: A handbook of methods, CAB International, Commonwealth Agricultural Bureaux (CAB) International, Wallingford, UK, 221 pp., 1989.

Arai, S., Ishizuka, S., Ohta, S., Ansori, S., Tokuchi, N., Tanaka, N., and Hardjono, A.: Potential $\mathrm{N}_{2} \mathrm{O}$ emissions from leguminous tree plantation soils in the humid tropics, Global Biogeochem. Cy., 22, GB2028, doi:10.1029/2007GB002965, 2008.

Baral, B., Kuyper, T., and Van Groenigen, J.: Liebig's law of the minimum applied to a greenhouse gas: alleviation of P-limitation reduces soil $\mathrm{N}_{2} \mathrm{O}$ emission, Plant Soil, 374, 539-548, 2014. 
Bouwman, A., Beusen, A., Griffioen, J., Van Groenigen, J., Hefting, M., Oenema, O., Van Puijenbroek, P., Seitzinger, S., Slomp, C., and Stehfest, E.: Global trends and uncertainties in terrestrial denitrification and $\mathrm{N}_{2} \mathrm{O}$ emissions, Philos. T. Roy. Soc. B., 368, 1-25, doi:10.1098/rstb.2013.0112, 2013.

Butterbach-Bahl, K., Kock, M., Willibald, G., Hewett, B., Buhagiar, S., Papen, H., and Kiese, R.: Temporal variations of fluxes of $\mathrm{NO}, \mathrm{NO}_{2}, \mathrm{~N}_{2} \mathrm{O}, \mathrm{CO}_{2}$, and $\mathrm{CH}_{4}$ in a tropical rain forest ecosystem, Global Biogeochem. Cy., 18, 1-11, doi:10.1029/2004GB002243, 2004.

Chalk, P. and Smith, C.: Chemodenitrification, in: Gaseous loss of nitrogen from plant-soil systems, Springer, 65-89, 1983.

Chen, H., Gurmesa, G. A., Zhang, W., Zhu, X. M., Zheng, M. H., Mao, Q. G., Zhang, T., and Mo, J. M.: Nitrogen saturation in humid tropical forests after 6 years of nitrogen and phosphorus addition: Hypothesis testing, Funct. Ecol., 30, 305-313, doi:10.1111/1365-2435.12475, 2015.

Cheng J., Oyang X., Huang D. W., Liu S. Z., Zhang D. Q., and Li Y. L.: Sap flow characteristics of four dominant tree species in a mixed conifer broadleaf forest in Dinghushan, Acta Ecologica Sinica, 35, 4097-4104, 2015 (in Chinese with English abstract).

Cicerone, R. J.: Changes in stratospheric ozone, Science, 237, 3542, 1987.

Cleveland, C. C. and Townsend, A. R.: Nutrient additions to a tropical rain forest drive substantial soil carbon dioxide losses to the atmosphere, P. Natl. Acad. Sci. USA, 103, 10316-10321, 2006.

Dalal, R. C. and Allen, D. E.: Greenhouse gas fluxes from natural ecosystems, Aust. J. Bot., 56, 369-407, 2008.

D’Amelio, M. T. S., Gatti, L. V., Miller, J. B., and Tans, P.: Regional $\mathrm{N}_{2} \mathrm{O}$ fluxes in Amazonia derived from aircraft vertical profiles, Atmos. Chem. Phys., 9, 8785-8797, doi:10.5194/acp9-8785-2009, 2009.

Davidson, E. A., Keller, M., Erickson, H. E., Verchot, L. V., and Veldkamp, E.: Testing a conceptual model of soil emissions of nitrous and nitric oxides, Bioscience, 50, 667-680, 2000.

Davidson, E. A., Nepstad, D. C., Ishida, F. Y., and Brando, P. M.: Effects of an experimental drought and recovery on soil emissions of carbon dioxide, methane, nitrous oxide, and nitric oxide in a moist tropical forest, Glob. Change Biol., 14, 2582-2590, 2008.

Erickson, H., Keller, M., and Davidson, E. A.: Nitrogen oxide fluxes and nitrogen cycling during postagricultural succession and forest fertilization in the humid tropics, Ecosystems, 4, 67-84, 2001.

Erickson, H., Davidson, E. A., and Keller, M.: Former land-use and tree species affect nitrogen oxide emissions from a tropical dry forest, Oecologia, 130, 297-308, 2002.

Fang, Y. T., Zhu, W. X., Gundersen, P., Mo, J. M., Zhou, G. Y., and Yoh, M.: Large loss of dissolved organic nitrogen from nitrogensaturated forests in subtropical China, Ecosystems, 12, 33-45, 2009.

Fang, Y. T., Gundersen, P., Mo, J. M., and Zhu, W. X.: Input and output of dissolved organic and inorganic nitrogen in subtropical forests of South China under high air pollution, Biogeosciences, 5, 339-352, doi:10.5194/bg-5-339-2008, 2008.

Fernandez, J., Dias, L., Barros, N., Novais, R., and Moraes, E.: Productivity of Eucalyptus camaldulensis affected by rate and placement of two phosphorus fertilizers to a Brazilian Oxisol, Forest Ecol. Manage., 127, 93-102, 2000.
Galloway, J. N., Dentener, F. J., Capone, D. G., Boyer, E. W., Howarth, R. W., Seitzinger, S. P., Asner, G. P., Cleveland, C. C., Green, P. A., Holland, E. A., Karl, D. M., Michaels, A. F., Porter, J. H., Townsend, A. R., and Vorosmarty, C. J.: Nitrogen cycles: past, present, and future, Biogeochemistry, 70, 153-226, 2004.

Galloway, J. N., Townsend, A. R., Erisman, J. W., Bekunda, M., Cai, Z., Freney, J. R., Martinelli, L. A., Seitzinger, S. P., and Sutton, M. A.: Transformation of the nitrogen cycle: recent trends, questions, and potential solutions, Science, 320, 889-892, 2008.

Graciano, C., Goya, J. F., Frangi, J. L., and Guiamet, J. J.: Fertilization with phosphorus increases soil nitrogen absorption in young plants of Eucalyptus grandis, Forest Ecol. Manage., 236, 202210, 2006.

Hall, S. J. and Matson, P. A.: Nitrogen oxide emissions after nitrogen additions in tropical forests, Nature, 400, 152-155, 1999.

Hall, S. J. and Matson, P. A.: Nutrient status of tropical rain forests influences soil $\mathrm{N}$ dynamics after $\mathrm{N}$ additions, Ecol. Monogr., 73, 107-129, 2003.

Hall, S. J., Asner, G. P., and Kitayama, K.: Substrate, climate, and land use controls over soil $\mathrm{N}$ dynamics and $\mathrm{N}$-oxide emissions in Borneo, Biogeochemistry, 70, 27-58, 2004.

Harrington, R. A., Fownes, J. H., and Vitousek, P. M.: Production and resource use efficiencies in N- and P-limited tropical forests: A comparison of responses to long-term fertilization, Ecosystems, 4, 646-657, 2001.

Hirsch, A., Michalak, A., Bruhwiler, L., Peters, W., Dlugokencky, E., and Tans, P.: Inverse modeling estimates of the global nitrous oxide surface flux from 1998-2001, Global Biogeochem. Cy., 20, GB1008, doi:10.1029/2004GB002443, 2006.

Holland, E. A., Robertson, G. P., Greenberg, J., Groffman, P. M., Boone, R. D., and Gosz, J. R.: Soil $\mathrm{CO}_{2}, \mathrm{~N}_{2} \mathrm{O}$, and $\mathrm{CH}_{4}$ exchange, in: Standard Soil Methods for Long-term Ecological Research, edited by: Robertson, G. P., Oxford University Press, USA, 185-201, 1999.

Huang, W. J., Liu, J. X., Wang, Y. P., Zhou, G. Y., Han, T. F., and $\mathrm{Li}$, Y.: Increasing phosphorus limitation along three successional forests in southern China, Plant Soil, 364, 181-191, 2013.

Huang, Z. F. and Fan, Z. G.: The climate of Dinghushan, Tropical and Subtropical Forest Ecosystem, 1, 11-16, 1982 (in Chinese with English abstract).

IPCC: Climate Change 2007 :The Physical Science Basis. Contribution of Working Group I to the Fouth Assessment Report of the Intergovermental Panel on Climate Change, Cambridge University Press, Cambridge, 2007.

Kiese, R., Hewett, B., and Butterbach-Bahl, K.: Seasonal dynamic of gross nitrification and $\mathrm{N}_{2} \mathrm{O}$ emission at two tropical rainforest sites in Queensland, Australia, Plant Soil, 309, 105-117, doi:10.1007/s11104-007-9468-1, 2008.

Koehler, B., Corre, M. D., Veldkamp, E., Wullaert, H., and Wright, S. J.: Immediate and long-term nitrogen oxide emissions from tropical forest soils exposed to elevated nitrogen input, Glob. Change Biol., 15, 2049-2-066, 2009.

Konda, R., Ohta, S., Ishizuka, S., Heriyanto, J., and Wicaksono, A.: Seasonal changes in the spatial structures of $\mathrm{N}_{2} \mathrm{O}, \mathrm{CO}_{2}$, and $\mathrm{CH}_{4}$ fluxes from Acacia mangium plantation soils in Indonesia, Soil Biol. Biochem., 42, 1512-1522, 2010.

Linn, D. and Doran, J.: Effect of water-filled pore space on carbon dioxide and nitrous oxide production in tilled and nontilled soils, Soil Sci. Soc. Am. J., 48, 1267-1272, 1984. 
Liu, G. S., Jiang, N. H., Zhang, L. D., and Liu, Z. L.: Soil Physical and Chemical Analysis and Description of Soil Profiles, China Standard Methods Press, Beijing, 33-167, 1996 (in Chinese).

Liu, L. and Greaver, T. L.: A review of nitrogen enrichment effects on three biogenic GHGs: the $\mathrm{CO}_{2}$ sink may be largely offset by stimulated $\mathrm{N}_{2} \mathrm{O}$ and $\mathrm{CH}_{4}$ emission, Ecol. Lett., 12, 1103-1117, 2009.

Liu, L., Gundersen, P., Zhang, T., and Mo, J. M.: Effects of phosphorus addition on soil microbial biomass and community composition in three forest types in tropical China, Soil Biol. Biochem., 44, 31-38, 2012.

Liu, L., Zhang, T., Gilliam, F. S., Gundersen, P., Zhang, W., Chen, H., and Mo, J. M.: Interactive effects of nitrogen and phosphorus on soil microbial communities in a tropical forest, PLoS One, 8 , e61188, doi:10.1371/journal.pone.0061188, 2013.

Lu, X., Gilliam, F. S., Yu, G., Li, L., Mao, Q., Chen, H., and Mo, J.: Long-term nitrogen addition decreases carbon leaching in a nitrogen-rich forest ecosystem, Biogeosciences, 10, 3931-3941, doi:10.5194/bg-10-3931-2013, 2013.

Lu, X. K., Mo, J. M., Gilliam, F. S., Zhou, G. Y., and Fang, Y. T.: Effects of experimental nitrogen additions on plant diversity in an old-growth tropical forest, Global Change Biol., 16, 2688-2700, 2010.

Magill, A. H., Aber, J. D., Berntson, G. M., McDowell, W. H., Nadelhoffer, K. J., Melillo, J. M., and Steudler, P.: Long-term nitrogen additions and nitrogen saturation in two temperate forests, Ecosystems, 3, 238-253, 2000.

Matson, P. A. and Vitousek, P. M.: Ecosystem approach to a global nitrous oxide budget, Bioscience, 40, 667-671, 1990.

Mo, J. M., Brown, S., Peng, S. L., and Kong, G. H.: Nitrogen availability in disturbed, rehabilitated and mature forests of tropical China, Forest Ecol. Manage., 175, 573-583, 2003.

Mo, J. M., Peng, S. L., Brown, S., Kong, G. H., and Fang, Y. T.: Nutrient dynamics in response to harvesting practices in a pine forest of subtropical China, Acta Phytoecol. Sin., 28, 810-822, 2004.

Mo, J. M., Brown, S., Xue, J. H., Fang, Y. T., and Li, Z. A.: Response of litter decomposition to simulated $\mathrm{N}$ deposition in disturbed, rehabilitated and mature forests in subtropical China, Plant Soil, 282, 135-151, 2006.

Mo, J. M., Brown, S., Xue, J. H., Fang, Y. T., Li, Z. A., Li, D. J., and Dong, S. F.: Response of nutrient dynamics of decomposing pine (Pinus massoniana) needles to simulated $\mathrm{N}$ deposition in a disturbed and a rehabilitated forest in tropical China, Ecol. Res., 22, 649-658, 2007a.

Mo, J. M., Zhang, W., Zhu, W. X., Fang, Y. T., Li, D. J., and Zhao, P.: Response of soil respiration to simulated $\mathrm{N}$ deposition in a disturbed and a rehabilitated tropical forest in southern China, Plant Soil, 296, 125-135, 2007b.

Mo, J., Zhang, W., Zhu, W., Gundersen, P., Fang, Y., Li, D., and Wang, H.: Nitrogen addition reduces soil respiration in a mature tropical forest in southern China, Glob. Change Biol., 14, 403412, 2008.

Mori, T., Ohta, S., Ishizuka, S., Konda, R., Wicaksono, A., Heriyanto, J., and Hardjono, A.: Effects of phosphorus addition on $\mathrm{N}_{2} \mathrm{O}$ and $\mathrm{NO}$ emissions from soils of an Acacia mangium plantation, Soil Sci. Plant Nutr., 56, 782-788, 2010.

Mori, T., Ohta, S., Ishizuka, S., Konda, R., Wicaksono, A., Heriyanto, J., and Hardjono, A.: Effects of phosphorus addition with and without ammonium, nitrate, or glucose on $\mathrm{N}_{2} \mathrm{O}$ and $\mathrm{NO}$ emissions from soil sampled under Acacia mangium plantation and incubated at $100 \%$ of the water-filled pore space, Biol. Fert. Soils, 49, 13-21, 2013.

Mori, T., Ohta, S., Ishizuka, S., Konda, R., Wicaksono, A., and Heriyanto, J.: Phosphorus application reduces $\mathrm{N}_{2} \mathrm{O}$ emissions from tropical leguminous plantation soil when phosphorus uptake is occurring, Biol. Fert. Soils, 50, 45-51, 2014.

Mørkved, P. T., Dörsch, P., and Bakken, L. R.: The $\mathrm{N}_{2} \mathrm{O}$ product ratio of nitrification and its dependence on long-term changes in soil pH, Soil Biol. Biochem., 39, 2048-2057, 2007.

Pampolina, N., Dell, B., and Malajczuk, N.: Dynamics of ectomycorrhizal fungi in an Eucalyptus globulus plantation: effect of phosphorus fertilization, For. Ecol. Manage., 158, 291-304, 2002.

Raison, R., Connell, M., and Khanna, P.: Methodology for studying fluxes of soil mineral-N in situ, Soil Biol. Biochem., 19, 521530, 1987.

Ravishankara, A., Daniel, J. S., and Portmann, R. W.: Nitrous oxide $\left(\mathrm{N}_{2} \mathrm{O}\right)$ : the dominant ozone-depleting substance emitted in the 21st century, Science, 326, 123-125, 2009.

Rowlings, D., Grace, P., Kiese, R., and Weier, K.: Environmental factors controlling temporal and spatial variability in the soilatmosphere exchange of $\mathrm{CO}_{2}, \mathrm{CH}_{4}$ and $\mathrm{N}_{2} \mathrm{O}$ from an Australian subtropical rainforest, Global Change Biol., 18, 726-738, 2012.

Skiba, U., Pitcairn, C., Sheppard, L., Kennedy, V., and Fowler, D.: The influence of atmospheric $\mathrm{N}$ deposition on nitrous oxide and nitric oxide fluxes and soil ammonium and nitrate concentrations, Water Air Soil Poll., 4, 37-43, 2004.

Sousa Neto, E., Carmo, J. B., Keller, M., Martins, S. C., Alves, L. F., Vieira, S. A., Piccolo, M. C., Camargo, P., Couto, H. T. Z., Joly, C. A., and Martinelli, L. A.: Soil-atmosphere exchange of nitrous oxide, methane and carbon dioxide in a gradient of elevation in the coastal Brazilian Atlantic forest, Biogeosciences, 8, 733-742, doi:10.5194/bg-8-733-2011, 2011.

Sundareshwar, P., Morris, J., Koepfler, E., and Fornwalt, B.: Phosphorus limitation of coastal ecosystem processes, Science, 299, 563-565, 2003.

Tang, X. L., Liu, S. G., Zhou, G. Y., Zhang, D. Q., and Zhou, C. Y.: Soil-atmospheric exchange of $\mathrm{CO}_{2}, \mathrm{CH}_{4}$, and $\mathrm{N}_{2} \mathrm{O}$ in three subtropical forest ecosystems in southern China, Global Change Biol., 12, 546-560, 2006.

Tate, R. L.: Soil microbiology, John Wiley and Sons, 398 pp., 1995.

Treseder, K. K. and Vitousek, P. M.: Effects of soil nutrient availability on investment in acquisition of $\mathrm{N}$ and $\mathrm{P}$ in Hawaiian rain forests, Ecology, 82, 946-954, 2001.

Vance, E., Brookes, P., and Jenkinson, D.: An extraction method for measuring soil microbial biomass C, Soil Biol. Biochem., 19, 703-707, 1987.

Venterea, R. T., Groffman, P. M., Verchot, L. V., Magill, A. H., Aber, J. D., and Steudler, P. A.: Nitrogen oxide gas emissions from temperate forest soils receiving long term nitrogen inputs, Global Change Biol., 9, 346-357, 2003.

Verchot, L. V., Davidson, E. A., Cattânio, H., Ackerman, I. L., Erickson, H. E., and Keller, M.: Land use change and biogeochemical controls of nitrogen oxide emissions from soils in eastern Amazonia, Global Biogeochem. Cy., 13, 31-46, 1999. 
Vitousek, P. M. and Matson, P. A.: Nitrogen transformations in a range of tropical forest soils, Soil Biol. Biochem., 20, 361-367, 1988.

Vitousek, P. M. and Farrington, H.: Nutrient limitation and soil development: experimental test of a biogeochemical theory, Biogeochemistry, 37, 63-75, 1997.

Vitousek, P. M., Aber, J. D., Howarth, R. W., Likens, G. E., Matson, P. A., Schindler, D. W., Schlesinger, W. H., and Tilman, D. G.: Human alteration of the global nitrogen cycle: sources and consequences, Ecol. Appl., 7, 737-750, 1997.

Vitousek, P. M., Porder, S., Houlton, B. Z., and Chadwick, O. A.: Terrestrial phosphorus limitation: mechanisms, implications, and nitrogen-phosphorus interactions, Ecol. Appl., 20, 5-15, 2010.

Wang, F. M., Li, J., Wang, X. L., Zhang, W., Zou, B., Neher, D. A., and Li, Z. A.: Nitrogen and phosphorus addition impact soil $\mathrm{N}_{2} \mathrm{O}$ emission in a secondary tropical forest of South China, Sci. Rep-UK, 4, 1-8, doi:10.1038/srep05615, 2014.

Wang, H., Liu, S. R., Mo, J. M., and Zhang, T.: Soil-atmosphere exchange of greenhouse gases in subtropical plantations of indigenous tree species, Plant Soil, 335, 213-227, 2010.

Wang, Y. H., Wang, Y. S., and Ling, H.: A new carrier gas type for accurate measurement of $\mathrm{N}_{2} \mathrm{O}$ by GC-ECD, Adv. Atmos. Sci., 27, 1322-1330, 2010.

Wang, Z. H., He, D. Q., Song, S. D., Chen, S. P., Chen, D. R., and Tu, M. Z.: The vegetation of Dinghushan Biosphere Reserve (in Chinese with English abstract), Tropical and Subtropical Forest Ecosystem, 1, 77-141, 1982.

Werner, C., Zheng, X. H., Tang, J. W., Xie, B. H., Liu, C. Y., Kiese, R., and Butterbach-Bahl, $\mathrm{K} .: \mathrm{N}_{2} \mathrm{O}, \mathrm{CH}_{4}$ and $\mathrm{CO}_{2}$ emissions from seasonal tropical rainforests and a rubber plantation in Southwest China, Plant Soil, 289, 335-353, 2006.

Werner, C., Kiese, R., and Butterbach-Bahl, K.: Soil-atmosphere exchange of $\mathrm{N}_{2} \mathrm{O}, \mathrm{CH}_{4}$, and $\mathrm{CO}_{2}$ and controlling environmental factors for tropical rain forest sites in western Kenya, J. Geophys. Res, 112, D03308, doi:10.1029/2006JD007388, 2007.

Wieder, W. R., Cleveland, C. C., and Townsend, A. R.: Throughfall exclusion and leaf litter addition drive higher rates of soil nitrous oxide emissions from a lowland wet tropical forest, Global Change Biol., 17, 3195-3207, 2011.

WMO: Greenhouse Gas Bulletin: The State of Greenhouse Gases in the Atmosphere Based on Global Observations through 2011, 2012.
Zhang, T., Zhu, W., Mo, J., Liu, L., and Dong, S.: Increased phosphorus availability mitigates the inhibition of nitrogen deposition on $\mathrm{CH}_{4}$ uptake in an old-growth tropical forest, southern China, Biogeosciences, 8, 2805-2813, doi:10.5194/bg-8-28052011, 2011.

Zhang, W., Mo, J. M., Yu, G. R., Fang, Y. T., Li, D. J., Lu, X. K., and Wang, H.: Emissions of nitrous oxide from three tropical forests in Southern China in response to simulated nitrogen deposition, Plant Soil, 306, 221-236, 2008a.

Zhang, W., Mo, J. M., Zhou, G. Y., Gundersen, P., Fang, Y. T., Lu, X. K., Zhang, T., and Dong, S. F.: Methane uptake responses to nitrogen deposition in three tropical forests in southern China, J. Geophys. Res, 113, D11116, doi:10.1029/2007JD009195, 2008 b.

Zhang, W., Zhu, X. M., Luo, Y. Q., Rafique, R., Chen, H., Huang, J., and Mo, J. M.: Responses of nitrous oxide emissions to nitrogen and phosphorus additions in two tropical plantations with $\mathrm{N}$ fixing vs. non-N-fixing tree species, Biogeosciences, 11, 49414951, doi:10.5194/bg-11-4941-2014, 2014.

Zheng, M. H., Huang, J., Chen, H., Wang, H., and Mo, J. M.: Responses of soil acid phosphatase and beta-glucosidase to nitrogen and phosphorus addition in two subtropical forests in southern China, Eur. J. Soil Biol., 68, 77-84, 2015.

Zheng, X. H., Mei, B. L., Wang, Y. H., Xie, B. H., Wang, Y. S., Dong, H. B., Xu, H., Chen, G. X., Cai, Z. C., and Yue, J.: Quantification of $\mathrm{N}_{2} \mathrm{O}$ fluxes from soil-plant systems may be biased by the applied gas chromatograph methodology, Plant Soil, 311, 211-234, 2008.

Zhu, F. F., Yoh, M., Gilliam, F. S., Lu, X. K., and Mo, J. M.: Nutrient limitation in three lowland tropical forests in southern China receiving high nitrogen deposition: insights from fine root responses to nutrient additions, PLoS One, 8, e82661, doi:10.1371/journal.pone.0082661, 2013.

Zhu, J., Mulder, J., Wu, L. P., Meng, X. X., Wang, Y. H., and Dörsch, P.: Spatial and temporal variability of $\mathrm{N}_{2} \mathrm{O}$ emissions in a subtropical forest catchment in China, Biogeosciences, 10, 1309-1321, doi:10.5194/bg-10-1309-2013, 2013. 